Prepared in cooperation with the Idaho Department of Environmental Quality and Cassia, Gooding, Jerome, Lincoln, Minidoka, and Twin Falls Counties

\title{
A Graphical Modeling Tool for Evaluating Nitrogen Loading to and Nitrate Transport in Ground Water in the Mid-Snake Region, South-Central Idaho
}

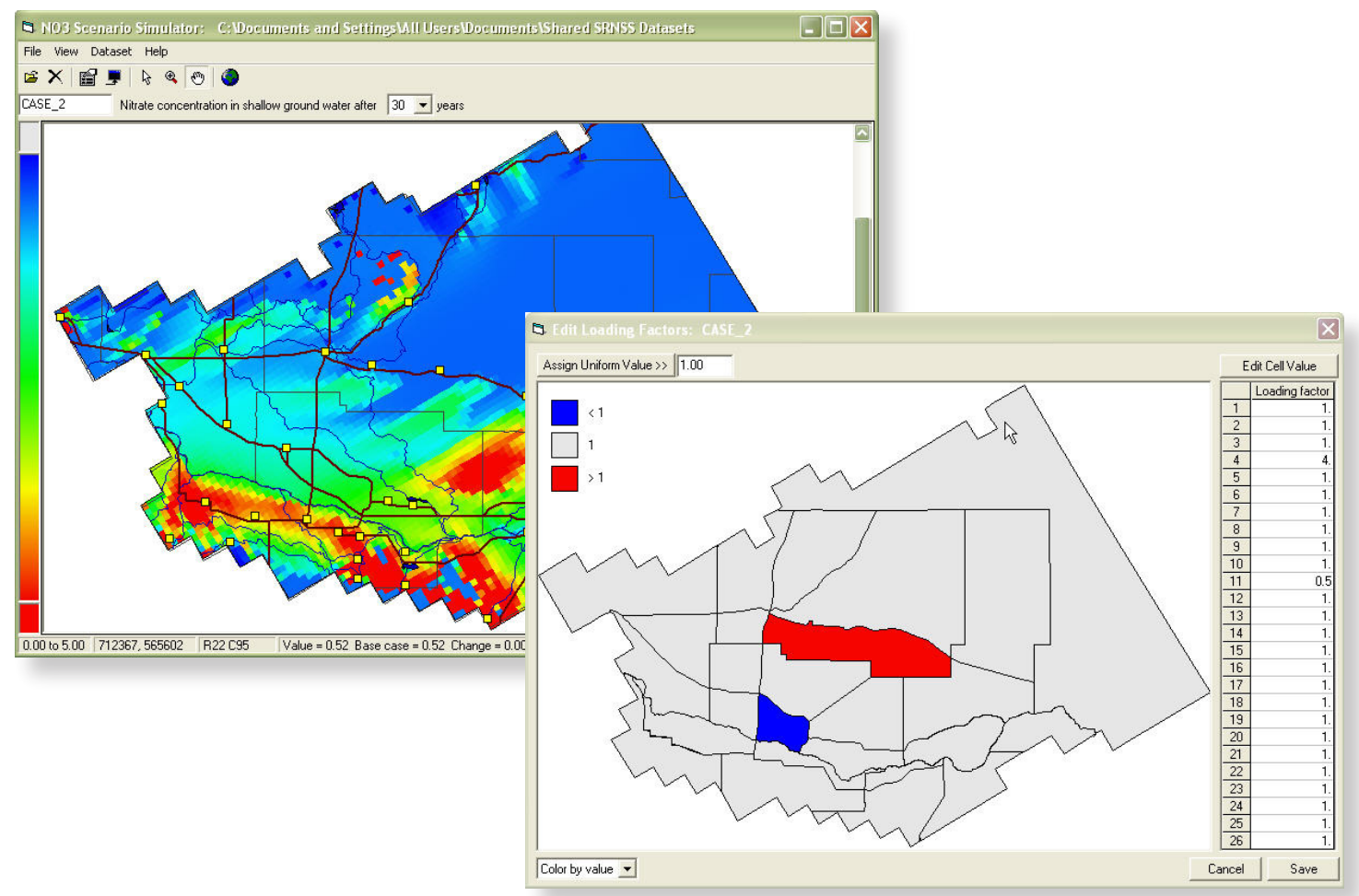

Scientific Investigations Report 2006-5137 



\section{A Graphical Modeling Tool for Evaluating Nitrogen Loading to and Nitrate Transport in Ground Water in the Mid-Snake Region, South-Central Idaho}

By David W. Clark, Kenneth D. Skinner, and David W. Pollock

Prepared in cooperation with the Idaho Department of Environmental Quality and Cassia, Gooding, Jerome, Lincoln, Minidoka, and Twin Falls Counties

Scientific Investigations Report 2006-5137 


\section{U.S. Department of the Interior \\ Dirk A. Kempthorne, Secretary \\ U.S. Geological Survey \\ P. Patrick Leahy, Acting Director}

For product and ordering information:

World Wide Web: http://www.usgs.gov/pubprod

Telephone: 1-888-ASK-USGS

For more information on the USGS--the Federal source for science about the Earth, its natural and living resources, natural hazards, and the environment:

World Wide Web: http://www.usgs.gov

Telephone: 1-888-ASK-USGS

Any use of trade, product, or firm names is for descriptive purposes only and does not imply endorsement by the U.S. Government.

Although this report is in the public domain, permission must be secured from the individual copyright owners to reproduce any copyrighted materials contained within this report.

Suggested citation:

Clark, David W., Skinner, Kenneth D., and Pollock, David W., 2006, A graphical modeling tool for evaluating nitrogen loading to and nitrate transport in ground water in the mid-Snake Region, south-central Idaho: U.S. Geological Survey Scientific Investigations Report 2006-5137, 32 p. 


\section{Contents}

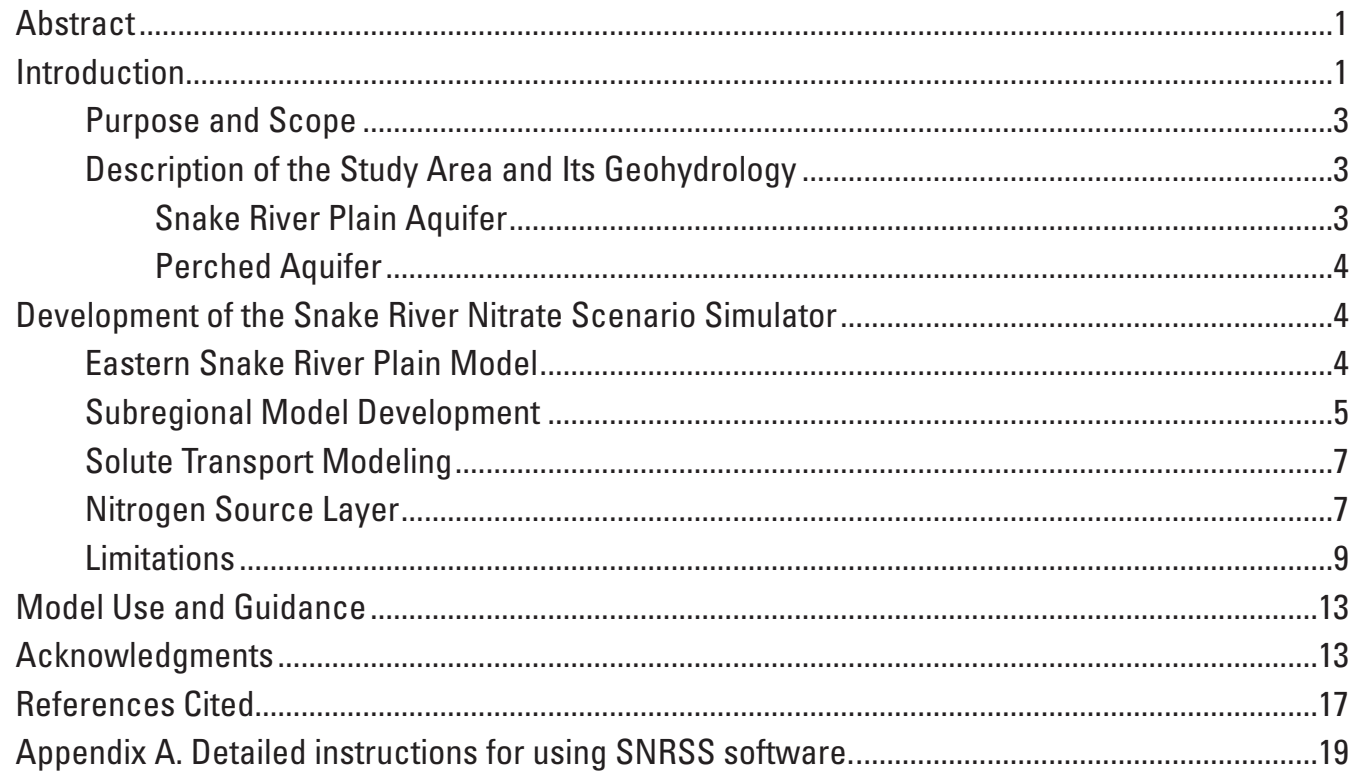

\section{Figures}

Figure 1. Map showing location of the study area, south-central Idaho

Figure 2. Map showing extent of a subregional ground-water flow model of the mid-Snake region within the eastern Snake River Plain regional model environment

Figure 3. Map showing nitrogen loading input representing 1998 for the study area, south-central Idaho

8

Figure 4. Chart showing multiplication factor applied to the nitrogen loading layer during each flow model stress period

Figure 5. Map showing measured and simulated nitrate concentrations (nitrite + nitrate as nitrogen) in the mid-Snake region, south-central Idaho $\ldots \ldots \ldots \ldots \ldots \ldots \ldots \ldots \ldots$

Figure 6. Graphs showing measured and simulated nitrate concentrations (nitrite plus nitrate as nitrogen) at Box Canyon Spring, south-central Idaho, 1999-2001

Figure 7. Map showing simulated ground-water velocity from the subregional flow model in the mid-Snake region, south-central Idaho

Figure 8. Map showing predefined nitrogen loading zones in south-central Idaho used in the SRNSS flow and transport model

Figure 9. Map showing nitrogen input range by dairy cattle by zone in south-central Idaho 16 


\section{Tables}

Table 1. Nitrogen input values for source and land-use type for counties in the study area, south-central Idaho

Table 2. Percentage of area occupied by nitrogen source types in each zone of the study area, south-central Idaho

\section{Conversion Factors, Datums, Abbreviated Water-Quality Units, Acronyms, and Symbols}

Conversion Factors

\begin{tabular}{lll}
\hline Multiply & By & To obtain \\
\hline foot $(\mathrm{ft})$ & 0.3048 & meter \\
foot squared per day $\left(\mathrm{ft}^{2} / \mathrm{d}\right)$ & 0.09290 & meter squared per day \\
gallon per minute $(\mathrm{gal} / \mathrm{min})$ & 0.06309 & liter per second \\
inch (in.) & 2.54 & centimeter \\
mile $(\mathrm{mi})$ & 1.609 & kilometer \\
pounds per acre per year $[(\mathrm{lb} / \mathrm{acre}) / \mathrm{yr}]$ & 1.121 & kilograms per hectare per year \\
square mile $\left(\mathrm{mi}^{2}\right)$ & 2.590 & square kilometer \\
\hline
\end{tabular}

Datums

Vertical coordinate information is referenced to the North American Vertical Datum of 1988 (NAVD 88).

Horizontal coordinate information is referenced to the North American Datum of 1983 (NAD 83).

Transmissivity: The standard unit for transmissivity is cubic foot per day per square foot times aquifer thickness in feet [(ft $\left./ \mathrm{d}) / \mathrm{ft}^{2}\right] \mathrm{ft}$. In this report, the mathematically reduced form, foot squared per day $\left(\mathrm{ft}^{2} / \mathrm{d}\right)$, is used for convenience.

Abbreviated Water-Quality Units, Acronyms, and Symbols

\begin{tabular}{cl}
\hline $\begin{array}{c}\text { Acronym/Water-Quality } \\
\text { Unit/Symbol }\end{array}$ & \multicolumn{1}{c}{ Definition } \\
\hline GIS & $\begin{array}{l}\text { Geographic Information Systems } \\
\text { graphical user interface }\end{array}$ \\
GUI & eastern Snake River Plain \\
ESRP & Idaho Department of Environmental Quality \\
IDEQ & milligram per liter \\
mg/L & National Water-Quality Assessment \\
NAWQA & National Water Information System \\
NWIS & Regional Aquifer-System Analysis \\
RASA & Snake River Nitrate Scenario Simulator \\
SRNSS & U.S. Geological Survey \\
USGS & less than or equal to \\
$\leq$ &
\end{tabular}




\title{
A Graphical Modeling Tool for Evaluating Nitrogen Loading to and Nitrate Transport in Ground Water in the Mid-Snake Region, South-Central Idaho
}

\author{
By David W. Clark, Kenneth D. Skinner, and David W. Pollock
}

\section{Abstract}

A flow and transport model was created with a graphical user interface to simplify the evaluation of nitrogen loading and nitrate transport in the mid-Snake region in south-central Idaho. This model and interface package, the Snake River Nitrate Scenario Simulator, uses the U.S. Geological Survey's MODFLOW 2000 and MOC3D models. The interface, which is enabled for use with geographic information systems (GIS), was created using ESRI's royalty-free MapObjects LT software. The interface lets users view initial nitrogenloading conditions (representing conditions as of 1998), alter the nitrogen loading within selected zones by specifying a multiplication factor and applying it to the initial condition, run the flow and transport model, and view a graphical representation of the modeling results.

The flow and transport model of the Snake River Nitrate Scenario Simulator was created by rediscretizing and recalibrating a clipped portion of an existing regional flow model. The new subregional model was recalibrated with newly available water-level data and spring and ground-water nitrate concentration data for the study area. An updated nitrogen input GIS layer controls the application of nitrogen to the flow and transport model. Users can alter the nitrogen application to the flow and transport model by altering the nitrogen load in predefined spatial zones contained within similar political, hydrologic, and size-constrained boundaries.

\section{Introduction}

Ground-water quality is an ongoing concern in Idaho. In 1990, ground water accounted for nearly 85 percent of the State's drinking water; in 1995, it accounted for almost 95 percent (Solley and others, 1993, 1998). Previous studies conducted in Idaho detected high concentrations of nitrate in many of the State's aquifers (Rupert, 1994; Crockett, 1995; Rupert and others, 1996). Previous studies also detected increasing concentrations of nitrate in a growing number of public- and domestic-use wells (Parliman and Young, 1987; Young and others, 1987a; Young and others, 1987b; Rupert, 1994; Clark and Ott, 1996; Rupert and others, 1996). The predominant sources of nitrate throughout much of the State are inorganic fertilizer, cattle manure, and legume crops (Rupert, 1996).

These increasing nitrate concentrations are of particular concern in the mid-Snake region of south-central Idaho. The region is experiencing substantial growth in some agricultural industries associated with the discharge of nitrogen to the environment, including dairies and other confined animal feeding operations. Gooding, Jerome, and Twin Falls Counties are experiencing particular growth in dairy operations (Idaho Agricultural Statistics Service, 1999; U.S. Department of Agriculture, 1999). These potential new sources of nitrogen to ground water are additional to those sources from existing, long-term agricultural activities in the region. Because of declining ground-water quality in parts of the mid-Snake region, the Idaho Department of Environmental Quality (IDEQ) designated those areas as priority water-quality management areas and targeted them for further study and assistance to improve land-use planning, nitrogen monitoring, and nitrogen management. At present (2006), planners and resource managers in the region lack analysis tools that could assist them in land-use planning and in managing and protecting water resources. When they attempt to evaluate how new and proposed changes to land use might affect their water resources, they must do so on an operation-by-operation basis without the ability to consider the cumulative effects from all nitrogen sources.

In response to these concerns and needs, the IDEQ proposed a project to study nitrogen loading effects and to develop planning tools to help assess how various land-use decisions might affect nitrate concentrations in the region's ground water. The IDEQ asked the U.S. Geological Survey (USGS) to conduct an investigation in the mid-Snake region of south-central Idaho that comprises Jerome and Minidoka Counties and parts of Blaine, Bingham, Butte, Camas, Cassia, Elmore, Gooding, Lincoln, Power, and Twin Falls Counties (fig. 1). 


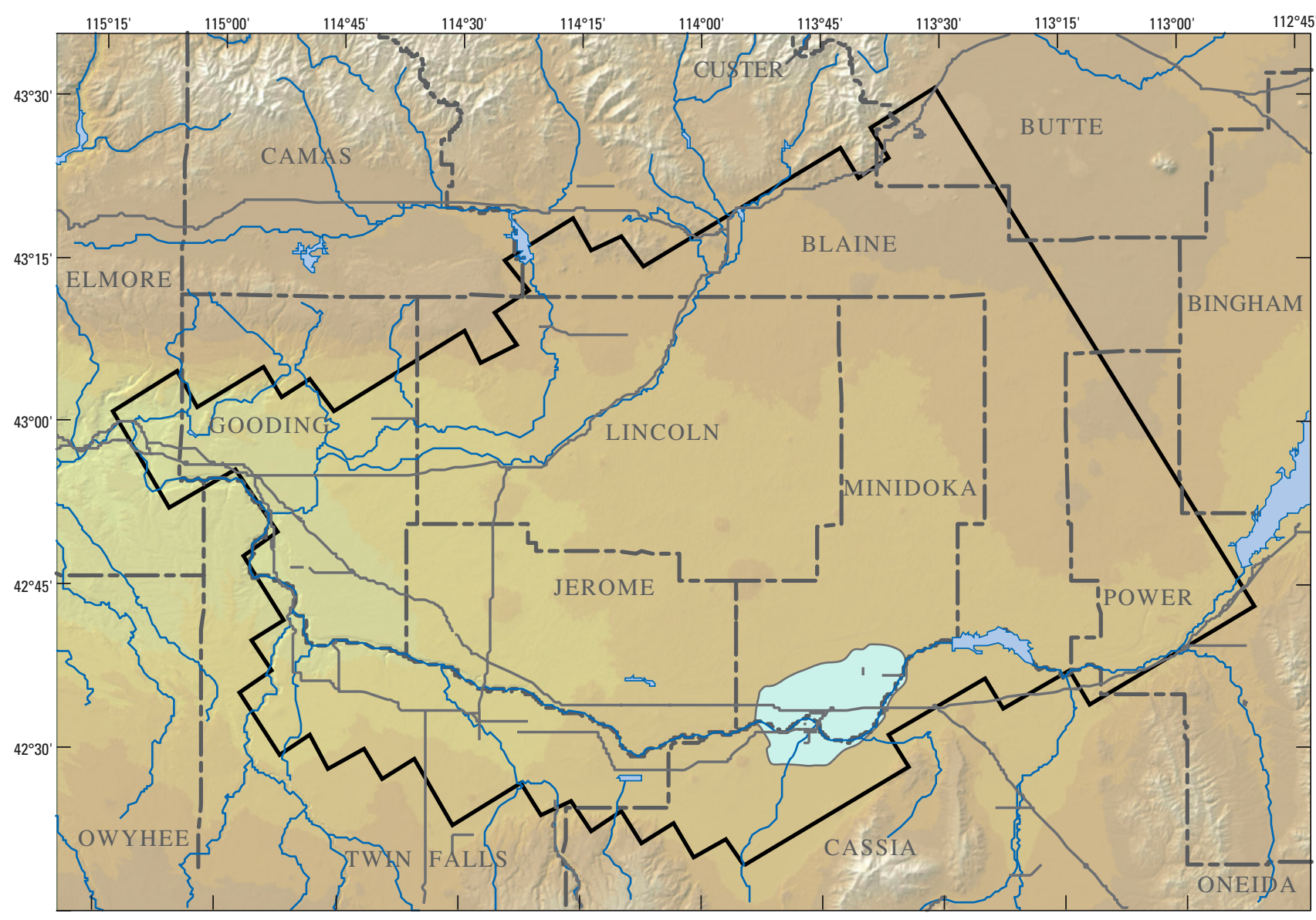

Basemap modified from U.S. Geological Survey, digital data, 1:100,000, 1999

Transverse_Mercator projection

False_Easting: 500000.000000

False_Northing: 100000.000000

Central_Meridian: -114.000000

Scale Factor: 0.999600

Latitude_Of Origin: 42.000000

Horizontal datum is North American Datum 1983
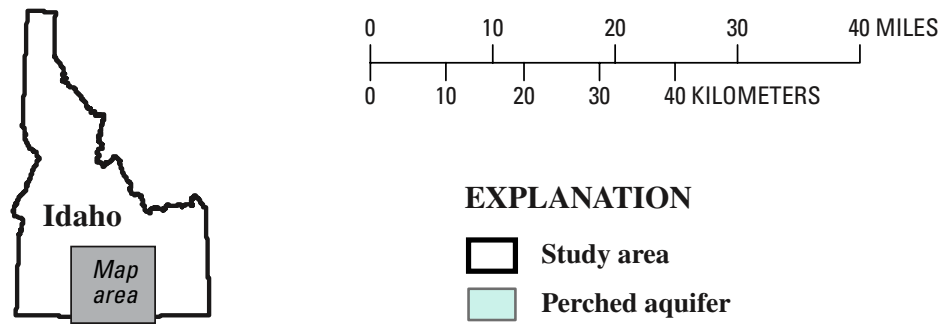

EXPLANATION

Study area

Perched aquifer

Figure 1. Location of the study area, south-central Idaho. 


\section{Purpose and Scope}

The purpose of the study was to improve understanding of past and future effects of land-use-related nitrogen loading on ground water in the study area. Specific objectives were:

1. Define nitrogen sources to the ground-water system and evaluate relative loading from those sources as a function of both nitrate availability and the hydrogeologic characteristics of the source area.

2. Use computer simulations to evaluate conceptual models of nitrogen loading to and nitrate transport in ground water.

3. Evaluate the utility of applying computer models of nitrogen loading and nitrate transport to assessing the effects of land-use changes on nitrate concentrations in ground water.

Objective 1 was addressed by the investigation reported in Skinner and Donato, 2003. Objective 2 was addressed by the development of the simulator that accompanies this report. The simulator's graphical user interface (GUI) is enabled for use with geographic information systems (GIS). Objective 3 is addressed by this report, which documents the construction and calibration of the subregional flow and transport model, provides instructions for using the GIS-enabled GUI, and offers guidance for modeling the differences in nitrogen loading resulting from changes in land use.

To meet Objective 2, we developed a subregional model of the study area, based on a regional, three-dimensional ground-water flow model of the eastern Snake River Plain (ESRP model) that was developed and calibrated during the USGS Regional Aquifer System Analysis (RASA) program (Garabedian, 1992). Flow boundary conditions and initial estimates of aquifer properties for the new model were derived from the calibrated ESRP model.

Estimates of nitrogen loading to the aquifer, as well as measured distributions of nitrate concentrations in ground water, were used as data sources in a three-dimensional ground-water flow and transport model. The transport of dissolved nitrate in the ground-water system was simulated using the USGS three-dimensional solute-transport model MOC3D (Konikow and others, 1996, Kipp and others, 1998). Nitrogen input, developed as a separate part of the project and described in Skinner and Donato (2003), was used to help define nitrogen flux at the surface. Ground-water nitrate concentration data were used to calibrate and evaluate the transport model.

The scope of computer model development and assessment in this component of the study was limited to evaluating conceptual models of nitrogen loading, nitrate transport, and nitrate distribution in the region's ground-water system. General spatial and temporal trends observed in nitrate concentrations were compared with those estimated by the simulation model to evaluate the model's ability to represent loading and transport characteristics of the ground-water system, including concentrations of nitrate in a series of about 300 wells throughout the study area, and temporal nitrate concentrations from 11 springs that discharge into the Snake River.

Success in reproducing observed ground-water nitrate concentration trends using flow and transport models and estimates of nitrogen loads indicates that there is utility for applying computer nitrogen loading and nitrate transport models to assess the effects of land use and changes in land use on nitrate concentrations in ground water. This finding meets Objective 3 of the study. Other ground-water flow models that use MODFLOW as a basis for simulations, such as the one developed by the State of Idaho for the Snake River Plain (Cosgrove and others, 1999), could be adapted for use with the GIS enabled graphical simulator that was developed for this study.

\section{Description of the Study Area and Its Geohydrology}

Jerome and Minidoka Counties and parts of Blaine, Bingham, Butte, Camas, Cassia, Elmore, Gooding, Lincoln, Power, and Twin Falls Counties fall within the study area, which comprises 5,341 $\mathrm{mi}^{2}$ in south-central Idaho (fig. 1). The study area is in the downstream part of the eastern Snake River Plain. About 66 percent of the area is rangeland, 11 percent is flood-irrigated land, 21 percent is sprinkler-irrigated land, and the remaining 2 percent is comprised of several land-use types. The area is predominantly semiarid; mean annual precipitation ranges from 8 to $16 \mathrm{in}$. Therefore, most of the agricultural land in the study area lies near the Snake River, a major source of water for irrigation.

The ground-water system in the study area is made up of two types of aquifers: a regional basalt aquifer and a local perched alluvial aquifer. The regional basalt aquifer underlying the eastern Snake River Plain provides most of the ground water that moves through the study area. The local perched alluvial aquifer (fig. 1) overlying the eastern Snake River Plain in Minidoka and Cassia Counties is a lesser source of ground water and is not included in the flow and transport modeling.

\section{Snake River Plain Aquifer}

The eastern Snake River Plain aquifer, which encompasses the study area, is composed primarily of vesicular and fractured olivine basalt flows (Quaternary age) of the Snake River Group (Whitehead, 1992). These basalt flows average from 20 - to 25 -ft thick but can, in places, exceed $1,000-\mathrm{ft}$ thick. The top of the basalt is generally less than 100 $\mathrm{ft}$ below land surface throughout this part of the plain. 
Layered basalt flows in the eastern Snake River Plain aquifer yield exceptionally large volumes of water to wells and springs. Individual well yields are some of the highest in the Nation, typically ranging from 2,000 to 3,000 gal/min to as much as 7,000 gal/min with minimal drawdown (Whitehead, 1992; Lindholm, 1996). Transmissivity is commonly $100,000 \mathrm{ft}^{2} / \mathrm{d}$ and can be as high as $1,000,000 \mathrm{ft}^{2} / \mathrm{d}$ (Whitehead, 1992). Locally, aquifer properties can vary greatly; on a regional scale, however, the variability is minimal.

Regional ground water in the eastern Snake River Plain aquifer moves from the northeast to the southwest (Rupert, 1997). Ground water is discharged as springs and seeps to the Snake River along the reach bordering Twin Falls, Jerome, and Gooding Counties. Ground-water discharge to this reach of the Snake River increased considerably from about 1910 through the early 1950s (Kjelstrom, 1992). The increase is attributed to recharge from surface-water irrigation north of the Snake River. Since the early 1950s, ground-water discharge to the Snake River has decreased as a result of (1) increased ground-water withdrawals for irrigation (Moreland, 1976), (2) introduction of more efficient irrigation practices such as the conversion from flood to sprinkler irrigation, and (3) local droughts (Kjelstrom, 1992).

\section{Perched Aquifer}

In the Burley area, an alluvial aquifer is perched above a blue-clay layer about 60 to $120 \mathrm{ft}$ below land surface (Rupert, 1997). Water in this perched aquifer moves northward at the southern boundary of the perched aquifer and westward near the western boundary. The water level in the perched aquifer is about $100 \mathrm{ft}$ above that of the Snake River Plain aquifer. The perched aquifer is recharged predominantly from the infiltration of irrigation water. Several wells completed in this aquifer go dry seasonally after irrigation ceases and become operational again after the start of the next irrigation season (Rupert 1997).

\section{Development of the Snake River Nitrate Scenario Simulator}

The water resources of the mid-Snake region have been studied in investigations of regional and local hydrologic systems of Idaho, including investigations of the Snake River Plain in southern Idaho that were part of the USGS RASA and National Water-Quality Assessment (NAWQA) programs. The RASA and NAWQA programs in southern Idaho have produced an assemblage of geologic, hydrologic, and waterquality information about the region's ground-water systems, as well as computer simulation of those systems. For the
mid-Snake region study, we used this information, augmented with data collected in more recent and ongoing water-quality assessments of the area, to develop the Snake River Nitrate Scenario Simulator (SRNSS). Because similar information resources are available for much of the Snake River Plain, the investigation and tool-building approach developed in this study might be applicable to other priority water-quality management areas of the plain.

\section{Eastern Snake River Plain Model}

We based the configuration of the subregional model used in this study on a regional, three-dimensional ground-water flow model of the eastern Snake River Plain (ESRP model) that was developed and calibrated during the USGS RASA program (Garabedian, 1992). We derived flow boundary conditions and initial estimates of aquifer properties for the new subregional model from the calibrated ESRP model. Because the ESRP model and its use influenced our modeling approach, it is important to note here some of the ESRP modeling techniques described by Garabedian (1992) that we used to develop the subregional model for this study.

The goal of the eastern Snake River Plain modeling was to reproduce known aquifer conditions (for example, head and spring discharge) within reasonable ranges of values, and to examine the hydrologic effects of changes in model input data through sensitivity testing. Initial values of aquifer hydraulic properties, recharge, discharge, and pumpage were estimated for model input based on geologic and hydrologic information. Model output was compared with known aquifer conditions to determine whether the initial estimates were reasonable. The model was tested to determine its sensitivity to changes in transmissivity, storage coefficient, aquifer leakance, recharge, riverbed or spring-outlet conductance, ground-water pumpage, and boundary flux. Input data were adjusted within reasonable ranges to achieve a better fit to known conditions. Adjustments were made to least-known and to most-sensitive model parameters. Simulation results indicated how the aquifer might have responded to past stresses, such as increased pumping and reduced recharge, and how the aquifer might respond to hypothetical stresses in the future.

To model the regional aquifer system, assumptions were made about aquifer properties, hydraulic fluxes, and initial conditions for transient analysis. The three-dimensional finite-difference ground-water-flow model MODFLOW-88 (McDonald and Harbaugh, 1988) was used most extensively. Vertical variations in head within each model layer were assumed to be negligible, and head losses between layers were assumed to be controlled by confining beds near the base of each layer. Therefore, model-simulated heads were an approximate average of heads within that aquifer layer. 
According to Garabedian (1992), the regional aquifer system was subdivided vertically into four model layers. The layers were assigned equal thicknesses because differentiating the predominantly basalt aquifer system into distinct geohydrologic units was not possible. Layer 1 represents the upper $200 \mathrm{ft}$ of the aquifer system; layer 2 is the next $300 \mathrm{ft}$ below. Layers 1 and 2 contain Quaternary basalt of the Snake River Group and Tertiary basalt. Layers 3 and 4, are of lesser areal extent, and they are present only where basalt of the Snake River Group and interlayered sedimentary rocks are greater than 500 -ft thick. Layer 3 is $\leq 500 \mathrm{ft}$ in thickness, and is present only across the central part of the plain. Layer 4 ranges in thickness from 0 to about 3,000 ft in the central part of the plain.

Local aquifers perched above the regional aquifer system were not simulated, although recharge to perched aquifers was assumed to reach the regional aquifer. Vertical hydraulic conductivity was assumed to be anisotropic, owing to low-hydraulic-conductivity basalt between permeable flow tops and fine-grained layers within sand and gravel zones. Horizontal hydraulic conductivity was assumed to be isotropic because two-dimensional simulations indicated small differences in modeling results between isotropic and anisotropic conditions.

A steady-state model was constructed using 1980 wateryear fluxes (Garabedian, 1992, table 16). The 1980 fluxes were assumed to approximate the average annual flux for 1950-80. During that period, hydrologic conditions were stable relative to conditions from 1880 to 1950 . Groundwater recharge was assumed to equal discharge (steady-state conditions) from 1950 to 1980 because irrigation diversions and ground-water levels were assumed to be stable relative to conditions from 1880 to 1950 (Garabedian, 1992, fig. 8 and pl. 4). Declines in ground-water-level due to pumping, climatic variations, and decreased surface-water diversions during that period were generally small, and changes in storage were accordingly small (about 1 percent). These small changes in storage were included as a part of the recharge term by including them in the computation of approximate steady-state fluxes. Recharge from irrigation was assumed to take place directly below surface-water-irrigated areas.

Initial conditions were approximated by the steady-state solution obtained after removing recharge due to surfacewater irrigation and discharge by ground-water pumping from the calibrated 1950-80 steady-state model. Surface-water altitudes, used in the model for river-leakage simulations, were corrected for pre-reservoir conditions. The estimated preirrigation steady-state condition was a stable initial condition for transient simulation. Therefore, simulated changes in head and discharge were assumed to result from changes in model input fluxes rather than from non-equilibrium initial conditions.

\section{Subregional Model Development}

To develop the subregional model used in this report, we converted the calibrated ESRP flow model from Modflow-88 to MODFLOW 2000 (Harbaugh and others, 2000). Initial model runs were made on the calibrated regional model to calculate the quantity of ground-water flow across a newly-defined upgradient subregional model boundary. This boundary was set near the western boundary of Minidoka County at column 25 in the ESRP model (Garabedian, 1992).

We then "clipped" the ESRP RASA model grid to this new upgradient boundary. The original ESRP model grid was divided into square cells approximately $4 \mathrm{mi}$ per side. After the model area was reduced, the model area was rediscretized with each grid cell divided into approximately 1-mi square cells. Therefore, the number of grid cells increased by 16 times. A schematic drawing of this operation is illustrated in figure 2.

The subregional model includes only the western portion of the ESRP model. Flow values across column 25 of the ESRP model were input as constant flow into the subregional model cells along the upgradient boundary. The flow was input into these cells as line wells. The model was run with this new configuration and resultant water levels and budget values were checked against the original model. Results were nearly identical to the original model.

No changes were made to the model configuration that affected ground-water elevations, discharge from springs, recharge sources, and other critical values or conditions. Also, we did not change the hydraulic parameters from the original ESRP model. The only change to the subregional flow model resulted from the use of a much smaller grid cell size than the one used in the ESRP model. The ESRP model incorporated the use of wells as recharge sources. Because of the smaller grid size used in the subregional model, we needed to increase the number of cells into which recharge was input in order to more accurately incorporate the recharge volume; otherwise, the model would not match the original results. Therefore, the total volume of recharge remained the same as in the ESRP model, but this volume was distributed over 16 times the number of recharge wells. Wherever possible, we placed these additional recharge wells in the rediscretized adjacent grid cell blocks. The volume of each original recharge well was evenly distributed between the 16 smaller cells. A few minor adjustments in the locations of these new recharge wells were needed so the new simulations matched the original simulations, especially along the model boundary. 


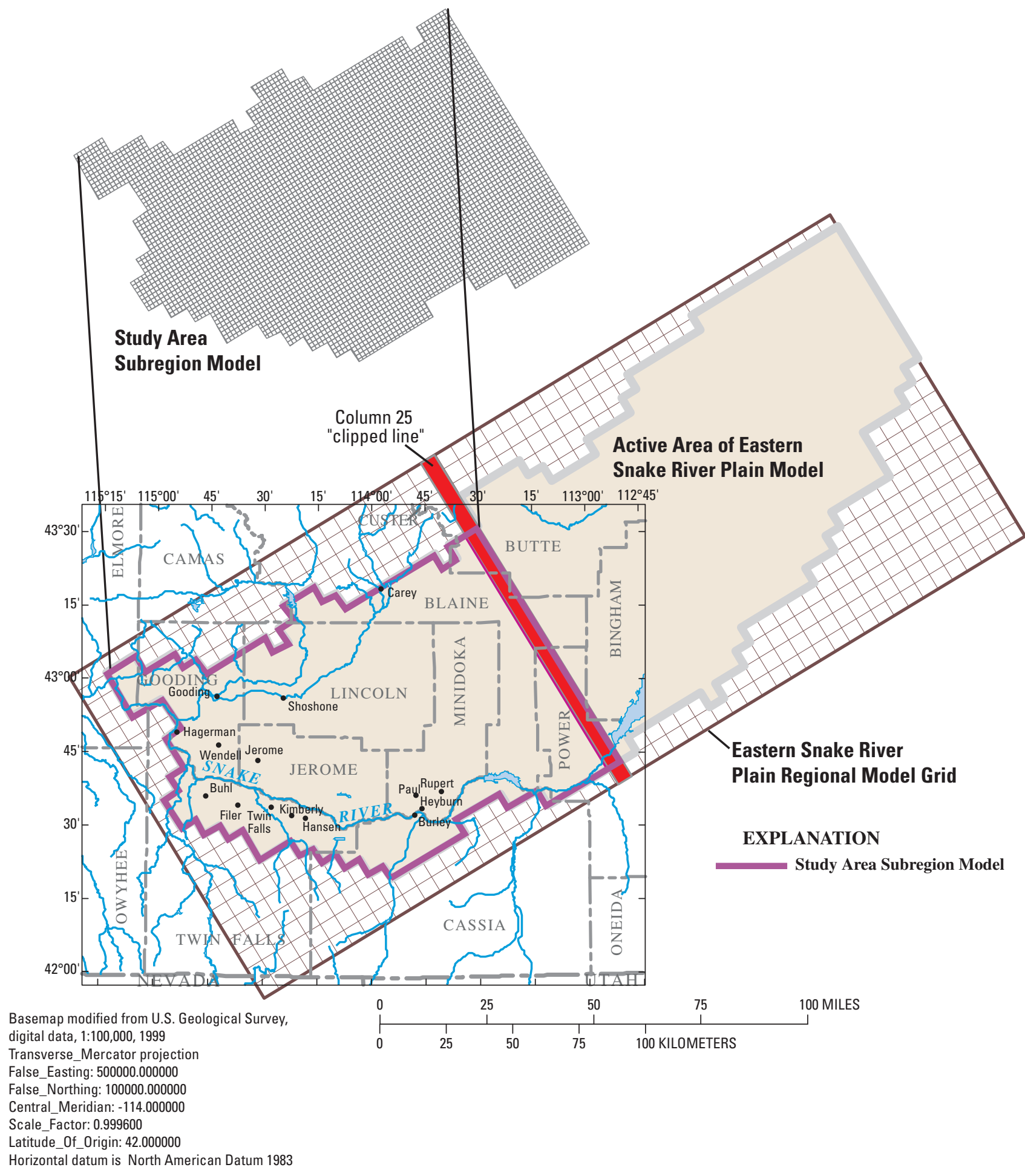

Figure 2. Extent of a subregional ground-water flow model of the mid-Snake region within the eastern Snake River Plain regional model environment. 


\section{Solute Transport Modeling}

We simulated the transport of dissolved nitrate in the mid-Snake region's ground-water system by using the USGS three-dimensional solute-transport model MOC3D (Konikow and others, 1996, Kipp and others, 1998), which was developed for use with MODFLOW 2000. MOC3D simulates three-dimensional solute transport in flowing ground water, computing changes in concentrations of a dissolved constituent over time that can be caused by factors such as advective transport, hydrodynamic dispersion, and mixing or dilution. MOC3D uses the method of characteristics to solve the transport equation for a given time step on the basis of hydraulic gradients computed with MODFLOW (Konikow and others, 1996, Kipp and others, 1998). Particle tracking is used within the model to represent advective transport. The conceptual model of nitrogen input developed by Skinner and Donato (2003) was used in the transport model as a GIS, nitrogen-input data layer. This nitrogen source layer was used to define nitrogen flux at the surface in the flow and transport model. The flow and transport models were simulated using steady-state conditions in three dimensions.

Data collected or compiled during recent and ongoing studies that define ground-water nitrate concentrations were used to refine the new model and to evaluate model calibration. All concentrations of nitrate are presented consistently as milligrams per liter of nitrite plus nitrate as nitrogen with negligible nitrite concentrations in the area.

\section{Nitrogen Source Layer}

Data used for nitrogen input into the solute transport model were calculated as a nitrogen-input layer during a separate study, and described in Skinner and Donato (2003). The input was updated to account for differences in study area extent between the two studies. This study's area includes additional areas of Bingham, Blaine, Butte, Camas, Elmore, and Power Counties; and less area of Cassia, Gooding, Lincoln, and Twin Falls Counties. The areas of the original nitrogen-input layer not in this study's area were simply "clipped off." The expanded portions of this study area are primarily upgradient to the solute transport model, and represent background conditions for nitrogen input. We assigned nitrogen-input values to the expanded study area portions that corresponded to similar approaches in the adjacent counties (fig. 3 ).

Input from the nitrogen source layer was incorporated in the MOC3D transport model by using the area wells function in all active model cells in layer 1 . The area wells function allows for the nitrogen source layer load to be introduced into the flow model by assigning a volumetric stress to each cell. The stress applied is a small volume of water that contains a specified concentration of nitrogen derived from the source layer. The initial pre-agriculture background concentration applied throughout the model was $0.5 \mathrm{mg} / \mathrm{L}$ in the upper model layer, $0.4 \mathrm{mg} / \mathrm{L}$ in the second and third underlying layers, and $0.3 \mathrm{mg} / \mathrm{L}$ in the fourth underlying layer. A very small stress term was initially given, and this term was adjusted based on available nitrogen in ground-water data in the USGS National Water Information System (NWIS) database. These data were used to refine the new model and to evaluate its calibration. The calibration points included about 300 wells located throughout the model area, and 11 springs that discharge into the Snake River. The well data usually included one analysis per well. The data for most of the bedrock springs discharging from the aquifer included many analyses over numerous years (Clark and Ott, 1996). The model continued to be simulated as steady state because the additional stress term was small in relation to overall stresses.

Calibration of the transport results was accomplished by comparing areal nitrate concentrations results from the simulations with nitrate data from the wells and springs. No rigorous calibration techniques, such as parameter estimation, were used in the calibration process because such techniques likely would have required changes to the underlying hydraulic parameters in the already-calibrated ESRP model, which was not part of the process. Therefore, calibration was done mostly using trial and error techniques.

Calibration began by taking the nitrogen source layer as representing current source conditions, and then adjusting it to start in 1910. County agricultural statistics for the six counties that overlap with Skinner and Donato (2003) were used to determine the total numbers of agricultural acres and dairy cattle. Those statistics were used to approximate the percentage of current nitrogen load that could be used to represent the 90 -year period. The amount of available nitrogen loading was increased during sequential model time steps by a factor related to those statistics (fig. 4). The result of the simulation, therefore, represents the end of a 90-year historical period simulation based on the increase in the area's crop farming and the introduction and increase of dairy farms.

Comparing maps of measured ground-water nitrate concentration data from the Skinner and Donato (2003) study area and simulated ground-water nitrate concentration data from this study and graphs of measured and simulated spring nitrate concentration data showed that the model was reasonably able to simulate the general pattern of measured nitrate concentrations (fig. 5). 


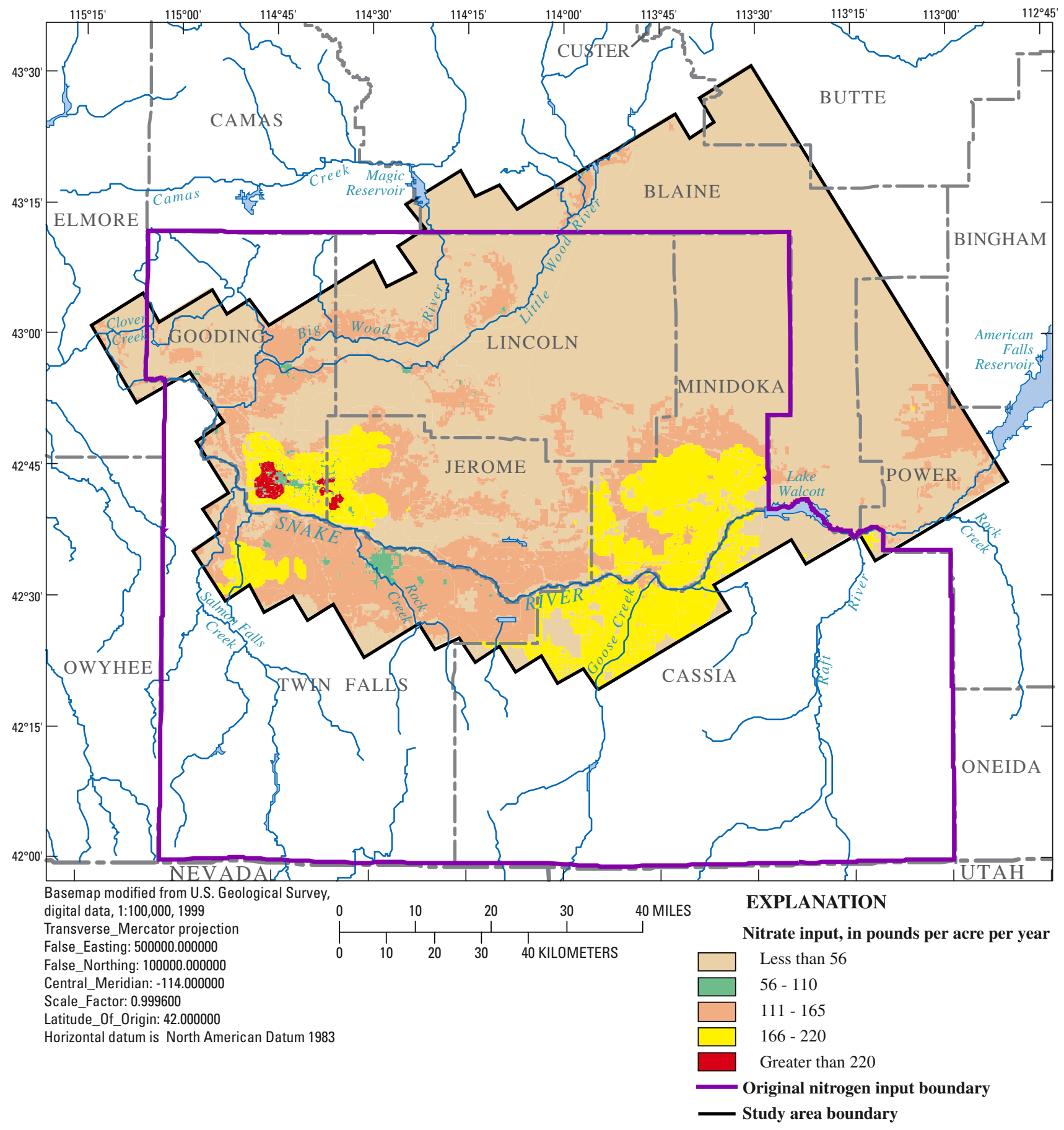

Figure 3. Nitrogen loading input representing 1998 for the study area, south-central Idaho. 


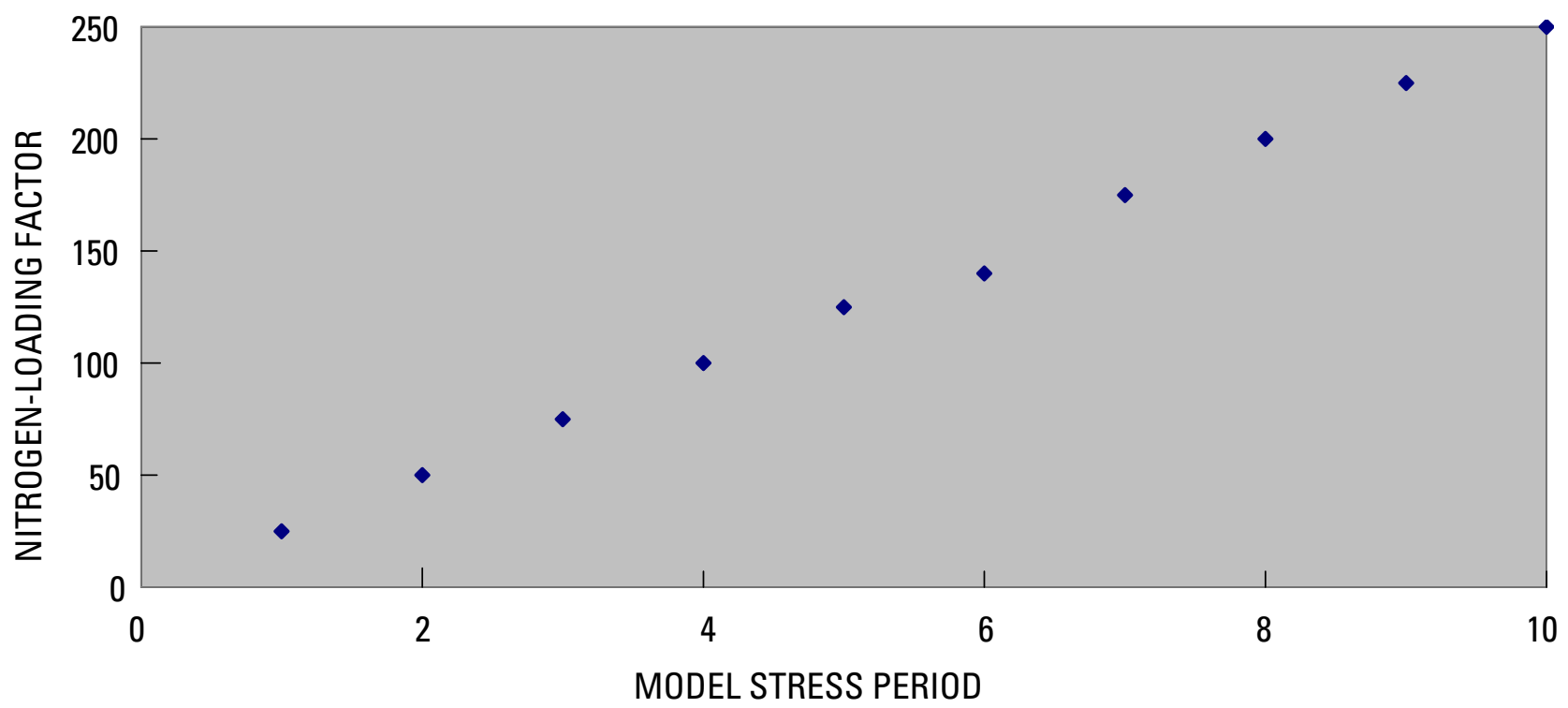

Figure 4. Multiplication factor applied to the nitrogen loading layer during each flow model stress period.

The springs flow from a bedrock wall, in a range of elevation of hundreds of feet and are therefore represented in model layers 1 and 2 . We input the vertical locations of these springs into the model, with most springs located in model layer 1 . The results of simulations indicated that the model was capable of approximating the nitrate concentrations for springs in both model layers (fig. 6). Simulated nitrate concentration was about $0.5 \mathrm{mg} / \mathrm{L}$ higher than data collected for a 3-year period from Box Canyon Spring and showed similar intra-annual variability. Simulated results represent nitrogen loading conditions from the same period as the measured data. The simulated results were acceptable for the objective of this project and model to simulate regional nitrate variability in response to changes in proportions of nitrogen sources.

Simulation results indicated that the nitrogen source layer was not necessarily the driving factor in the resulting nitrate concentration map; rather, the ground-water velocity appeared to be the prime controlling factor (fig. 7). Some areas with large nitrogen loads and large ground-water velocities resulted in relatively small simulated nitrate concentrations, and other areas with relatively small nitrogen loads and small groundwater velocities had large simulated ground-water nitrate concentrations. The simulated results reasonably represent the measured data.

\section{Limitations}

Data gathered from previous studies in the mid-Snake region, including USGS RASA and NAWQA programs, allow for the development and assessment of detailed conceptual and computer simulation models. These data and regional-scale RASA ground-water flow models are available for much of the Snake River Plain. Therefore, the approach used in this study is one potential assessment option for nitrate contamination issues in other areas of southern Idaho. However, the accuracy of such models will be limited because of the simplifying assumptions used in the models and uncertainty in model parameters. These limitations must be understood and considered when applying the model to resource-management issues. 

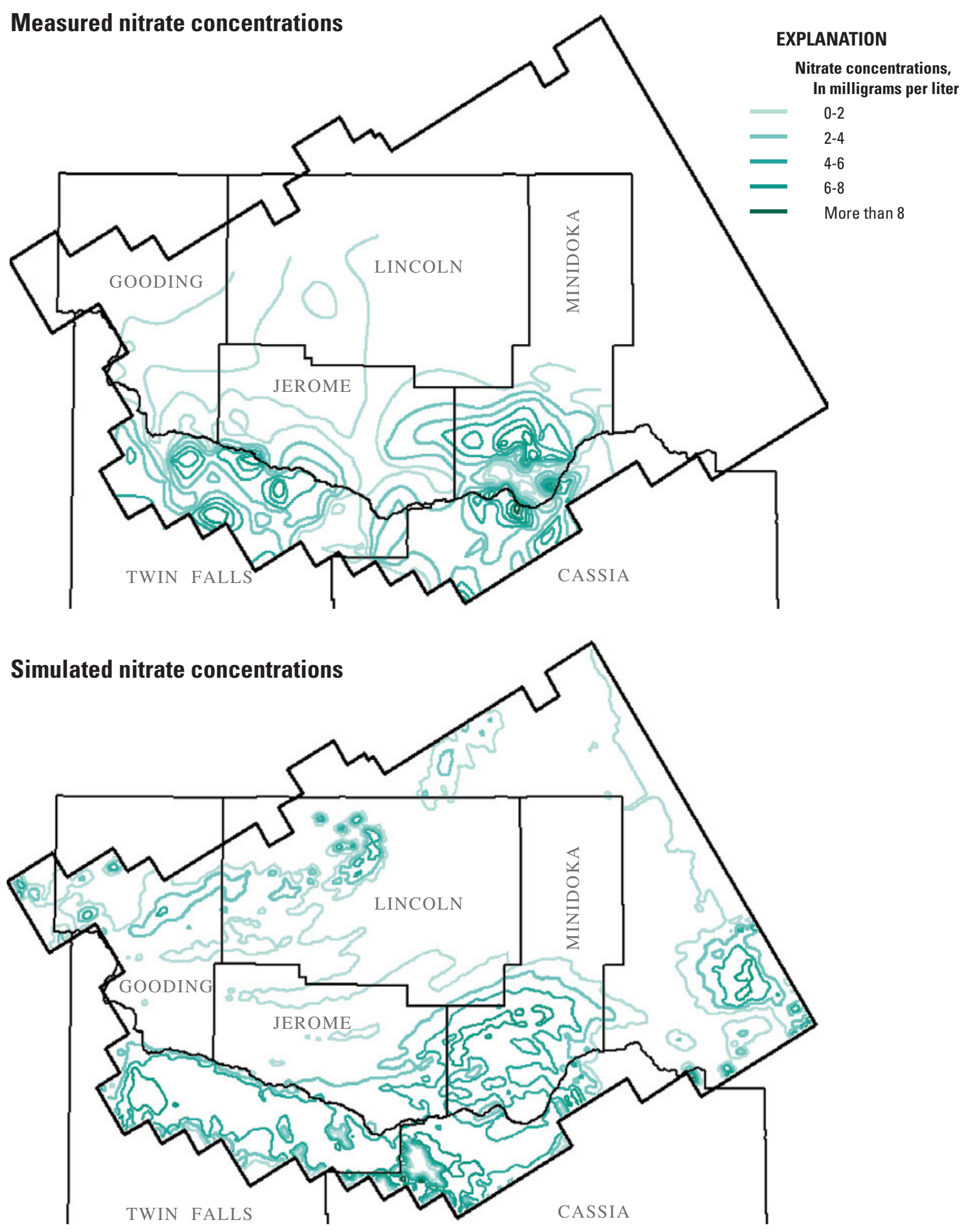

Figure 5. Measured and simulated nitrate concentrations (nitrite + nitrate as nitrogen) in the mid-Snake region, southcentral Idaho. 

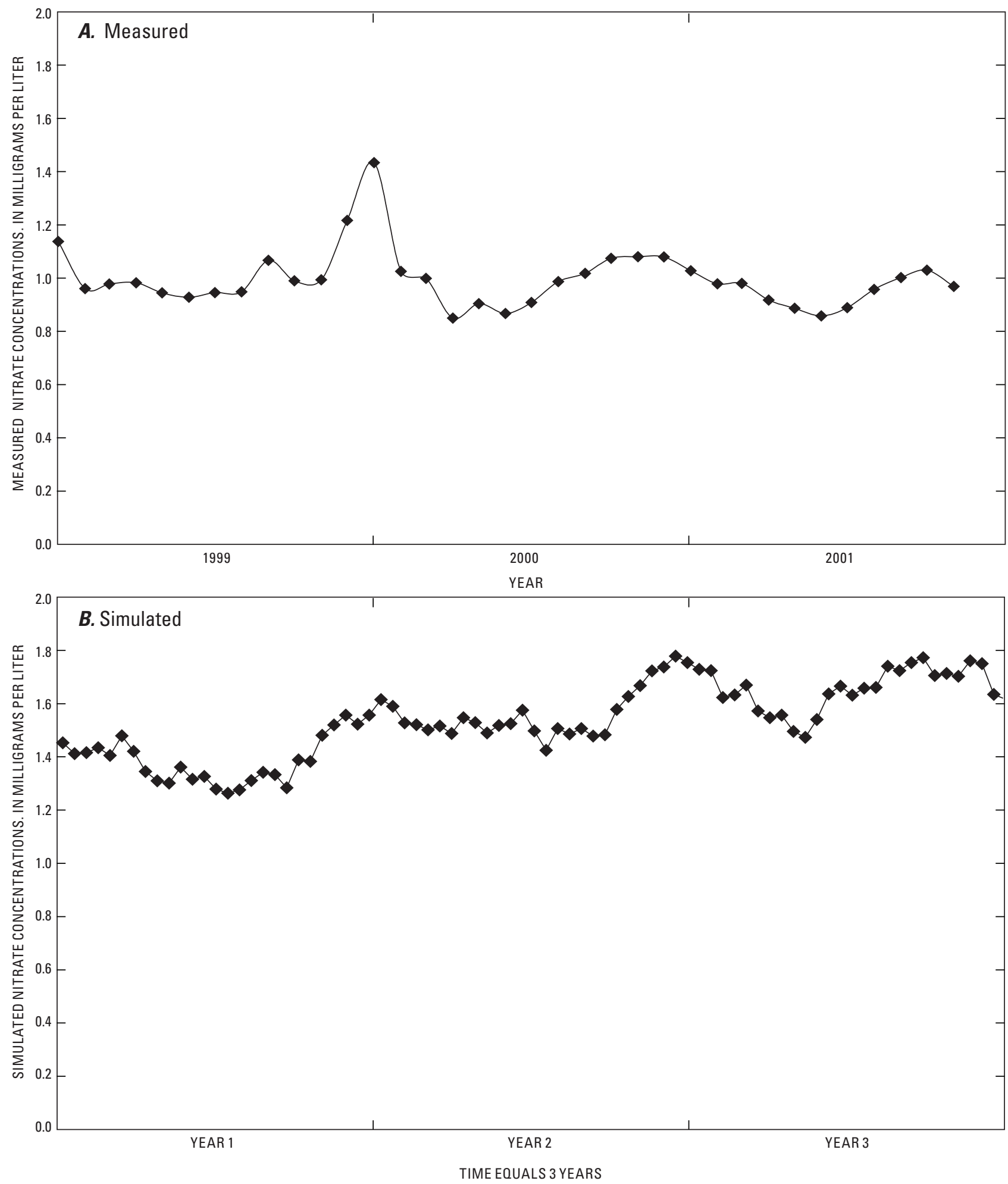

Figure 6. Measured and simulated nitrate concentrations (nitrite plus nitrate as nitrogen) at Box Canyon Spring, southcentral Idaho, 1999-2001. 


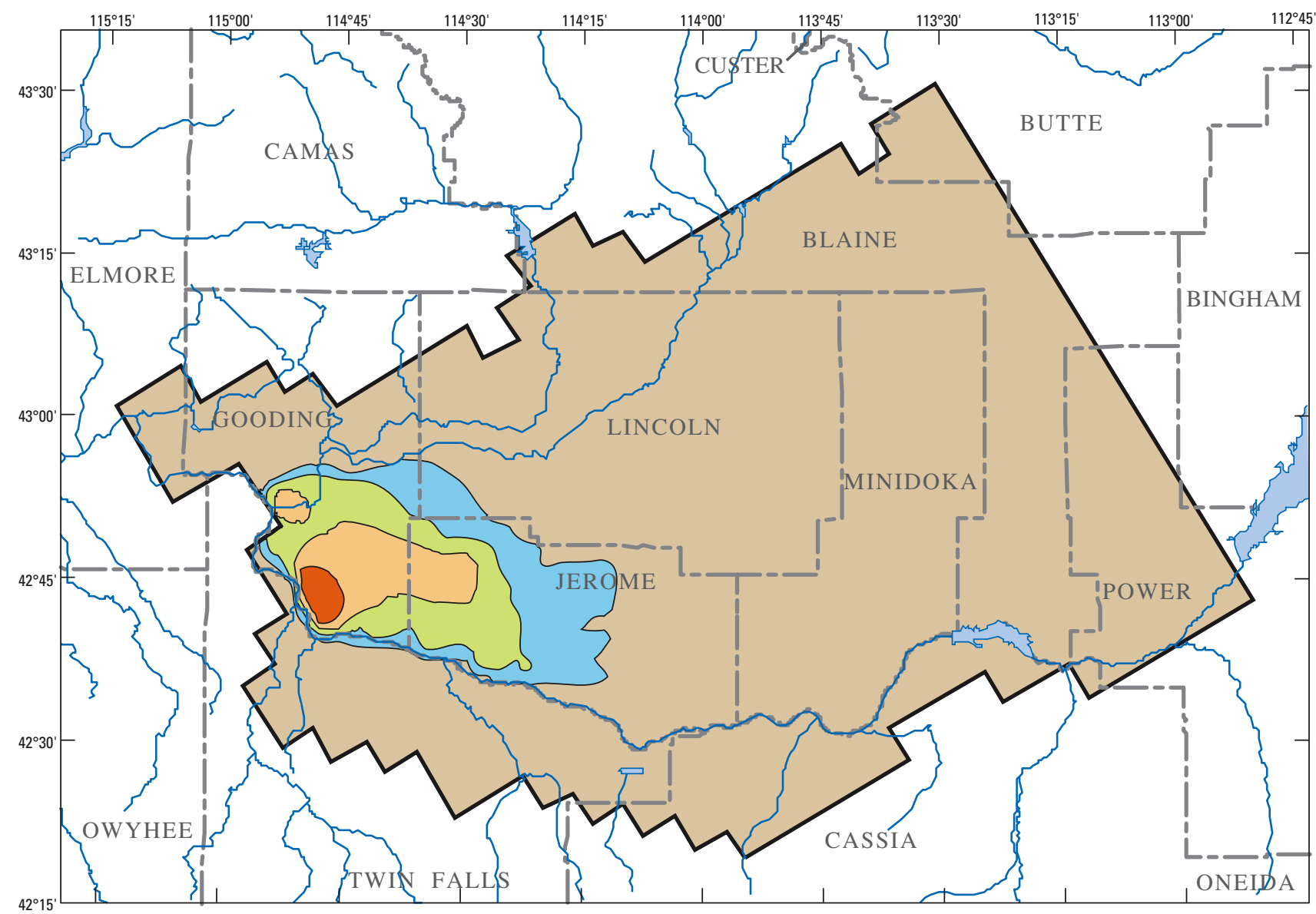

Basemap modified from U.S. Geological Survey, digital data, 1:100,000, 1999

Transverse_Mercator projection

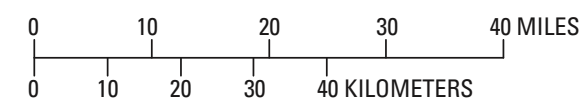

EXPLANATION

False Easting: 500000.000000

False_Northing: 100000.000000

Central_Meridian: -114.000000

Scale Factor: 0.999600

Latitude_Of_Origin: 42.000000

Horizontal datum is North American Datum 1983

round-water velocity, in feet per hour

Figure 7. Simulated ground-water velocity from the subregional flow model in the mid-Snake region, south-central Idaho. 


\section{Model Use and Guidance}

A GUI was created to simplify the alteration and display of the flow and transport model described above. The GUI was created using ESRI's royalty-free software MapObjects LT. The GUI provides a GIS interface for viewing and editing the nitrogen loading conditions, running the flow and transport model, and viewing the results of the modeling. The flow and transport model along with the GUI are collectively called the SRNSS. The components of the SRNSS and other associated files are available in a zip file that accompanies this report. One of the files, readme.txt, provides installation instructions. The appendix of this report provides detailed instructions for using the SNRSS software.

At startup, the SRNSS loads a base distribution of nitrogen loading and nitrate concentration distribution that represents the conditions in approximately the year 2000 . The base-case run represents the end of a 90-year historical period simulation of the increase in the area's farming and the introduction and increase of dairy farms. The increases in agriculture in the area are estimated from the U.S. Department of Agriculture's Census of Agriculture.

Users can then choose from predefined zones to increase or decrease the nitrogen loading for those zones by a multiplication factor of 0.1 to 5.0 (fig. 8). We delineated these predefined zones to maintain political, hydrological, and predominant land-use boundaries while preventing any one zone from becoming so small that the SRNSS could not simulate that zone effectively. For the same reason, the SRNSS does not allow users to create loading zones. After users edit the nitrogen loading zones, the SRNSS software prompts the users to run MODFLOW-MOC3D with the new nitrogen loading conditions. When MODFLOW-MOC3D completes its model run, the results are displayed in the simulator, allowing users to view the results in 5-year increments up to 30 years.

Altering the nitrogen loading factors simulates land-use changes for a zone. Nitrogen loads represent an entire zone that can contain multiple land-use types. Therefore, a change in nitrogen loading will represent a change from one predominant land use to another for the entire zone. The loading factor selected depends on the type of land-use change being modeled. For instance, a land-use change from rangeland to agriculture results in an increase in nitrogen loading that would be modeled by a loading factor between 1 and 5, depending on the amount and extent of the landuse change. Conversely, a land-use change from agriculture to residential results in a reduction of nitrogen loading and requires a loading factor between 0.1 and 0.9 . Other typical land-use change scenarios would be to convert agricultural land to rangeland, resulting in a decrease of loading (or a loading factor between 0 and 1), or to increase the dairy cattle in an area, modeled with a loading factor between 1 and 5, depending on the magnitude of the increase in dairy cattle. Choosing appropriate loading factors for simulating land-use change is left to the user, however, some guidance is provided below.

The nitrogen loading values used by the flow and transport model are based on fertilizer, cattle manure (from dairy and beef operations), septic systems, atmospheric deposition (precipitation), and legume crops (alfalfa and beans), with the largest inputs coming from fertilizer and dairy cattle. The nitrogen input data also account for crop uptake of nitrogen, listed as crop losses. Nitrogen inputs are countylevel estimates except those for dairy cattle and atmospheric deposition. Table 1 lists the nitrogen input and loss values for each county and land-use type as estimated in Skinner and Donato (2003), and describes the loading values for the 30year run used to create the base case in the SRNSS flow and transport model. Table 2 lists the percentage of area that each nitrogen input type (except precipitation, which is 100 percent for each zone) occupies within each zone. Nitrogen input for dairy cattle was applied by determining spatial densities of dairy cattle from known dairy locations. Dairy cattle densities ranged from 1 to 450 animals per square mile with an increase of $33 \mathrm{lbs}$ of nitrogen per acre per year for an increase of 50 per square mile (fig. 9). A more complete explanation of the nitrogen-loading layer is provided in Skinner and Donato (2003).

An example change in nitrogen loading input follows in which the predominant land-use changes from rangeland to dairy agriculture. The high nitrogen input values in southern Gooding and western Jerome Counties are primarily due to dairy cattle inputs (figs. 3 and 9). To change the nitrogenloading estimate for other parts of Gooding County to mimic the introduction of similar dairy cattle facilities would increase nitrogen loading by a multiplication factor of 2 to greater than 4 , depending on the original nitrogen input value. For example, the zone in northern Gooding County, primarily rangeland, would require a loading factor of 4 to resemble the nitrogen loading in southern Gooding County, primarily from dairy agriculture, (less than $55 \mathrm{lbs} / \mathrm{acre} / \mathrm{yr}$ to greater than $220 \mathrm{lbs} / \mathrm{acre} / \mathrm{yr})$.

In simulating changes in nitrogen inputs, be aware that the nitrogen inputs discussed above are general values representing large areas. Small spatial changes in land use cannot be simulated effectively with the SRNSS. However, large-area land-use changes occurring over long periods are ideal scenarios to simulate with the SRNSS.

\section{Acknowledgments}

The authors would like to acknowledge Michael Thomas (IDEQ) for his assistance in the evolution of this project. 


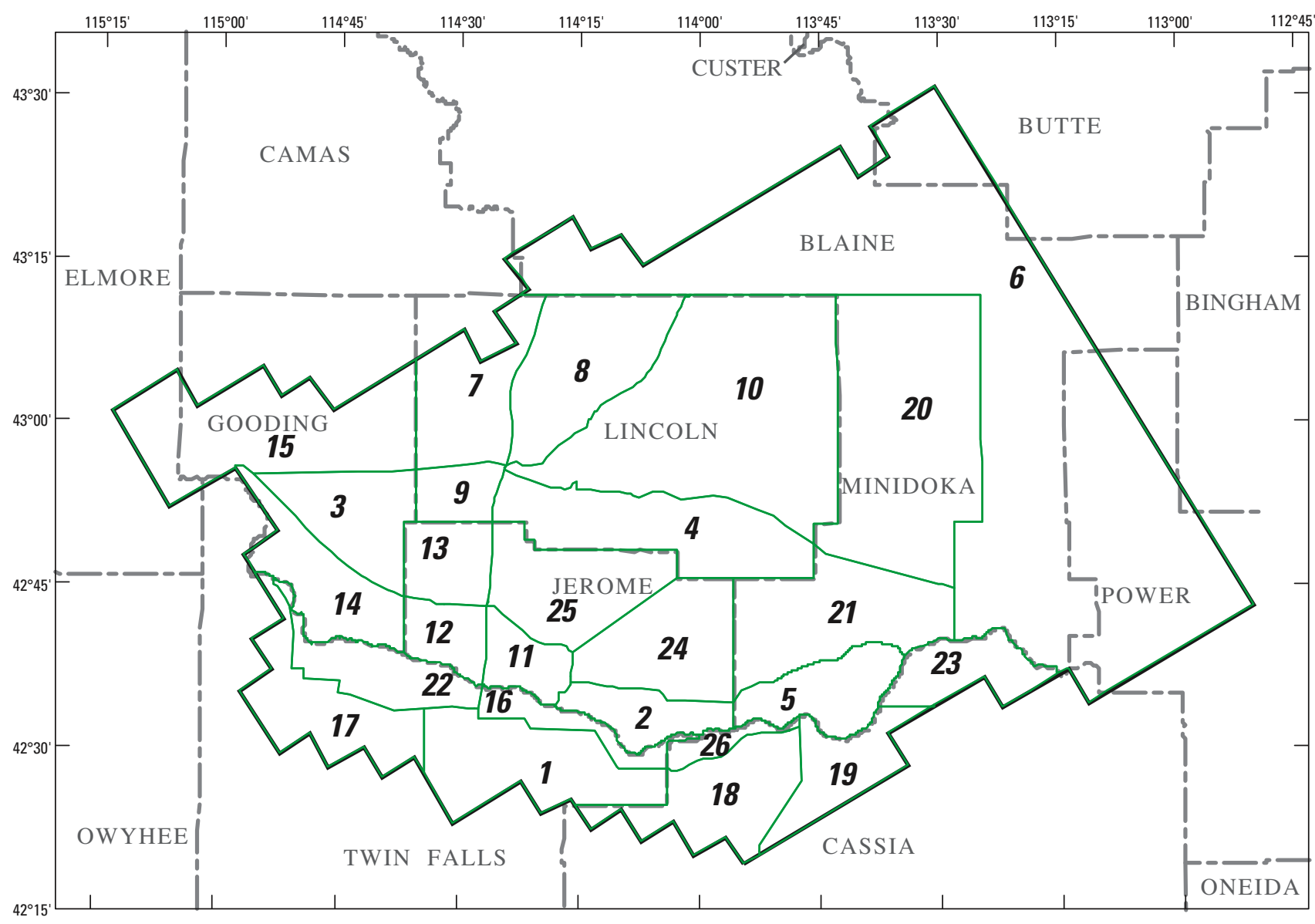

Base map modified from U.S. Geological Survey, digital data, 1:100,000, 1999

Transverse_Mercator projection

False_Easting: 500000.000000

False_Northing: 100000.000000

Central_Meridian: -114.000000

Scale_Factor: 0.999600

Latitude_Of_Origin: 42.000000

Horizontal datum is North American Datum 1983

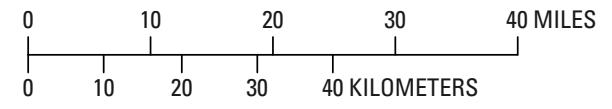

EXPLANATION

Predefined nitrogen loading zones

Figure 8. Predefined nitrogen loading zones in south-central Idaho used in the SRNSS flow and transport model. 
Table 1. Nitrogen input values for source and land-use type for counties in the study area, south-central Idaho.

[Nitrogen input values from 1998 data. Nitrogen input by dairy cattle and precipitation were not estimated by county, but by their own spatial distributions. Dairy cattle input varies widely due to animal population densities. Inputs range from 0 to 232 pounds per acre per year (lb/acre)/yr). Precipitation inputs range from 1 to 6 (lb/acre)/yr, with most of the area receiving 2 (lb/acre)/yr.

\begin{tabular}{lccccc}
\hline \multicolumn{5}{c}{ County } & \multicolumn{5}{c}{ Source and land-use type } \\
\cline { 2 - 6 } & $\begin{array}{c}\text { Fertilizer } \\
\text { (agricultural and } \\
\text { residential) }\end{array}$ & $\begin{array}{c}\text { Crop losses } \\
\text { (agricultural) }\end{array}$ & $\begin{array}{c}\text { Beef cattle } \\
\text { (agricultural) }\end{array}$ & $\begin{array}{c}\text { Septic } \\
\text { (residential and } \\
\text { commercial) }\end{array}$ & $\begin{array}{c}\text { Legumes } \\
\text { (agricultural) }\end{array}$ \\
\hline Cassia & 130 & -12 & 23 & 29 & 38 \\
Gooding & 67 & -7 & 30 & 16 & 58 \\
Jerome & 101 & -7 & 19 & 23 & 46 \\
Lincoln & 71 & -8 & 16 & 13 & 41 \\
Minidoka & 140 & -11 & 7 & 16 & 28 \\
Twin Falls & 90 & -8 & 16 & 16 & 49 \\
\hline
\end{tabular}

Table 2. Percentage of area occupied by nitrogen source types in each zone of the study area, south-central Idaho.

$\left\{\right.$ Percentage of area in square miles $\left(\mathrm{mi}^{2}\right)$.

\begin{tabular}{rrrrrrr}
\hline Zone & $\begin{array}{c}\text { Zone Area } \\
\left(\mathbf{m i}^{2} \boldsymbol{)}\right.\end{array}$ & Fertilizer & Septic & Legumes & Beef Cattle & Dairy Cattle \\
\hline 1 & 193 & 82 & 3 & 79 & 79 & 82 \\
2 & 76 & 87 & 0 & 87 & 87 & 48 \\
3 & 128 & 46 & 1 & 44 & 44 & 83 \\
4 & 221 & 25 & 0 & 25 & 25 & 30 \\
5 & 106 & 93 & 6 & 87 & 87 & 83 \\
6 & 1,407 & 9 & 0 & 9 & 0 & 0 \\
7 & 149 & 21 & 0 & 20 & 20 & 43 \\
8 & 200 & 21 & 0 & 20 & 20 & 60 \\
9 & 52 & 4 & 0 & 4 & 4 & 15 \\
10 & 532 & 4 & 0 & 3 & 3 & 9 \\
11 & 59 & 38 & 0 & 38 & 38 & 54 \\
12 & 60 & 79 & 5 & 74 & 74 & 96 \\
13 & 79 & 78 & 3 & 75 & 75 & 97 \\
14 & 130 & 71 & 2 & 69 & 69 & 28 \\
15 & 292 & 24 & 1 & 24 & 22 & 89 \\
16 & 53 & 79 & 9 & 70 & 70 & 22 \\
17 & 147 & 79 & 1 & 78 & 78 & 2 \\
18 & 151 & 71 & 1 & 70 & 70 & 80 \\
19 & 101 & 86 & 3 & 83 & 83 & 82 \\
20 & 440 & 12 & 0 & 12 & 12 & 45 \\
21 & 217 & 82 & 0 & 82 & 82 & 56 \\
22 & 103 & 74 & 5 & 70 & 70 & 18 \\
23 & 90 & 25 & 0 & 25 & 25 & 50 \\
24 & 163 & 35 & 0 & 34 & 34 & 26 \\
25 & 164 & 26 & 0 & 26 & 68 & \\
26 & 27 & 72 & 4 & 68 & & \\
\hline
\end{tabular}




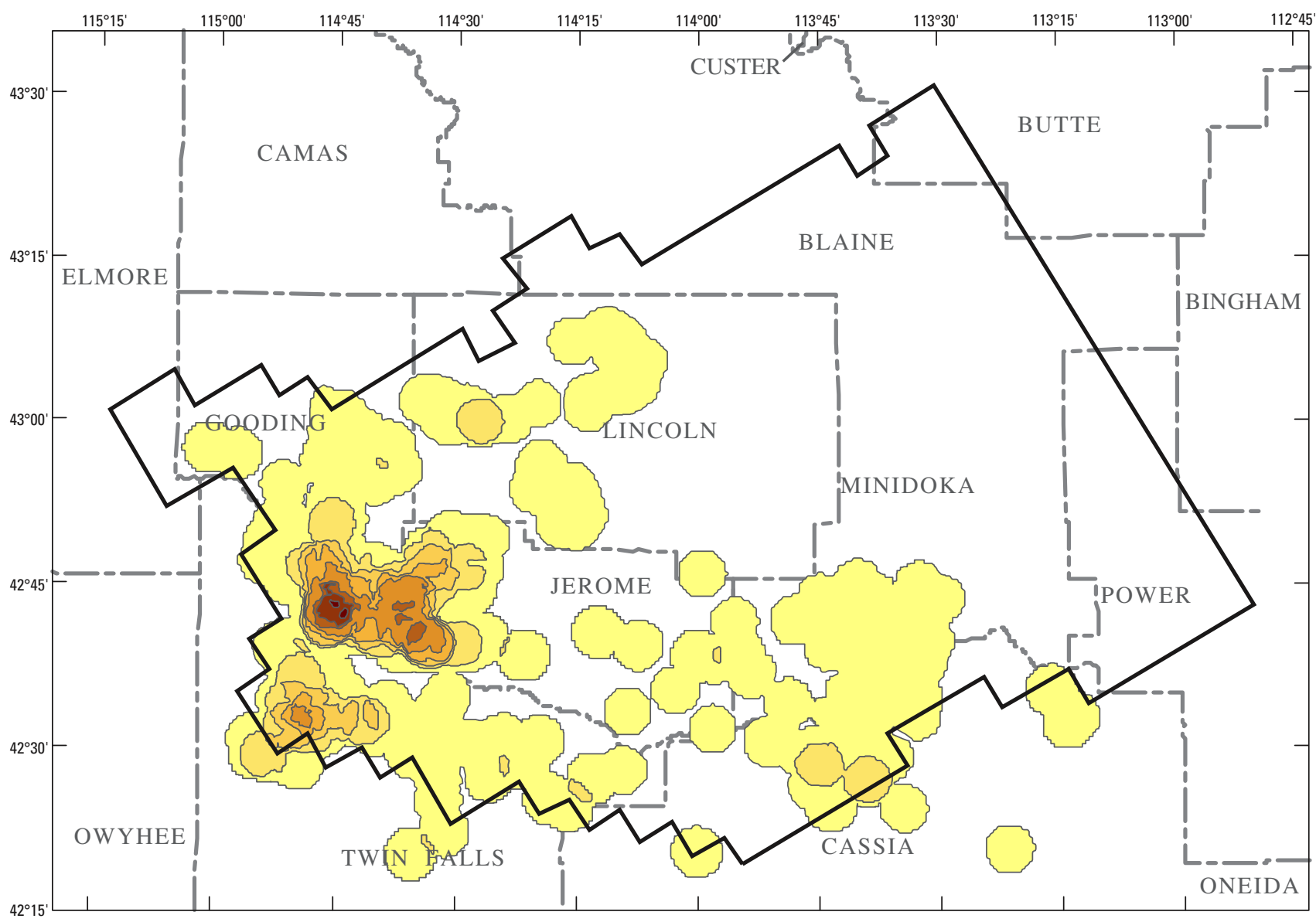

Base map modified from U.S. Geological Survey, digital data, 1:100,000, 1999 Transverse_Mercator projection

False Easting: 500000.000000

False_Northing: 100000.000000

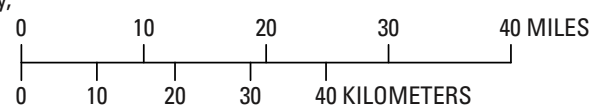

\section{EXPLANATION}

Nitrogen input by dairy cattle, in pounds per acre per year

Central Meridian:-114.000000

Scale_Factor: 0.999600

Latitude_Of_Origin: 42.000000

Horizontal datum is North American Datum 1983

Less than 2

2 - 33

$34-66$

$67-99$

$100-131$
132 - 197

198 - 230

231 - 296

Predefined nitrogen loading zones

19 SNRSS zone number

Figure 9. Nitrogen input range by dairy cattle by zone in south-central Idaho. 


\section{References Cited}

Clark, G.M., and Ott, D.S., 1996, Springflow effects on chemical loads in the Snake River, South-Central Idaho: Journal of the American Water Resources Association, v. 32, no. 3, p. 553-563.

Cosgrove, D.M., Johnson, G.S., Laney, S. and Lindgren, J., 1999, Description of the Snake River Plain Aquifer Model (SRPAM): Idaho Water Resources Research Institute, University of Idaho, Moscow, Idaho, $101 \mathrm{p}$.

Crockett, J.K., 1995, Idaho Statewide Ground Water Quality Monitoring Program—summary of results, 1991 through 1993: Idaho Department of Water Resources Water Information Bulletin no. 50, pt. 2, 67 p.

Garabedian, S.P., 1992, Hydrology and digital simulation of the regional aquifer system, eastern Snake River Plain, Idaho: U.S. Geological Survey Professional Paper 1408-F, 102 p., 10 pls.

Harbaugh, A.W., Banta, E.R., Hill, M.C., and McDonald, M.G., 2000, MODFLOW-2000, the U.S. Geological Survey modular ground-water model — User guide to modularization concepts and the Ground-Water Flow Process: U.S. Geological Survey Open-File Report 00-92, 121 p.

Idaho Agricultural Statistics Service, 1999, Idaho Agricultural Statistics: 65 p.

Kipp, K.L., Jr., Konikow, L.F., and Hornberger, G.Z., 1998, An implicit dispersive transport algorithim for the U.S. Geological Survey MOC3D solute-transport model: U.S. Geological Survey Water-Resources Investigations Report 98-4234, 54 p.

Kjelstrom, L.C., 1992, Assessment of spring discharge to the Snake River, Milner Dam to King Hill, Idaho: U.S. Geological Survey Water Fact Sheet, Open-File Report 92-147, 2 p.

Konikow, L.F., Goode, D.L., and Hornberger, G.Z., 1996, A three-dimensional method of characteristics solute-transport model (MOC3D): U.S. Geological Survey Water-Resources Investigations Report 96-4267, 87 p.

Lindholm, G.F., 1996, Summary of the Snake River Plain Regional Aquifer-System Analysis in Idaho and eastern Oregon: U.S. Geological Survey Professional Paper 1408-A, $59 \mathrm{p}$.

McDonald, M.G., and Harbaugh, A.W., 1988, A modular three-dimensional finite-difference ground-water flow model: U.S. Geological Survey Techniques of Water-Resources Investigations 06-A1, 586 p.

Moreland, J.A., 1976, Digital-model analysis of the effects of water-use alternatives on spring discharges, Gooding and Jerome Counties, Idaho: Boise, Idaho Department of Water Resources Water Information Bulletin 42, 46 p.
Parliman, D.J., and Young, H.W., 1987, Selected water-quality data for the Murtaugh Lake area, south-central Idaho, June 1987: U.S. Geological Survey Open-File Report 87-466, 1 sheet, scale 1:37,250.

Rupert, M.G., 1994, Analysis of data on nutrients and organic compounds in ground water in the upper Snake River Basin, Idaho and western Wyoming, 1980-91: U.S. Geological Survey Water-Resources Investigations Report 94-4135, $40 \mathrm{p}$.

Rupert, M.G., 1996, Major sources of nitrogen input and loss in the upper Snake River Basin, Idaho and western Wyoming, 1990: U.S. Geological Survey Water-Resources Investigations Report 96-4008, 15 p.

Rupert, M.G., 1997, Nitrate (NO2 + NO3 - N) in ground water of the upper Snake River Basin, Idaho and western Wyoming, 1991-95: U.S. Geological Survey Water-Resources Investigations Report 97-4174, 47 p.

Rupert, M.G., Stone, M.A.J., and Ott, D.S., 1996, National WaterQuality Assessment Program-nitrate and pesticides in ground water, Blaine, Cassia, Lincoln, and Minidoka Counties, southcentral Idaho: U.S. Geological Survey

Fact Sheet FS-246-95, 4 p.

Skinner, K.D., and Donato, M.M., 2003, Probability of detecting elevated concentrations of nitrate in ground water south-central Idaho: U.S. Geological Survey Water-Resources Investigations Report 03-4143, 29 p.

Solley, W.B., Pierce, R.R., and Perlman, H.A., 1993, Estimated use of water in the United States in 1990: U.S. Geological Survey Circular 1081, 76 p.

Solley, W.B., Pierce, R.R., and Perlman, H.A., 1998, Estimated use of water in the United States in 1995: U.S. Geological Survey Circular 1200, 71 p.

U.S. Department of Agriculture, 1999, Census of agriculture, Idaho State and county data: U.S. Department of Agriculture, National Agricultural Statistics Service, Geographic Area Series AC97-A-12, v. 1, part 12, 352 p.

Whitehead, R.L., 1992, Geohydrologic framework of the Snake River Plain regional aquifer system, Idaho and eastern Oregon: U.S. Geological Survey Professional Paper 1408-B, 32 p., 6 pls.

Young, H.W., Parliman, D.J., and Jones, M.L., 1987a, Selected water-quality data for the Burley irrigation district, southcentral Idaho, March-April, 1987: U.S. Geological Survey Open-File Report 87-240, 1 map.

Young, H.W., Parliman, D.J., and O’Dell, I., 1987b, Selected water-quality data for the Minidoka Irrigation District, southcentral Idaho, June 1987: U.S. Geological Survey Open-File Report 87-465, 1 map. 
This page left intentionally blank 


\section{Appendix A. Detailed instructions for using SNRSS software.}

This appendix provides the following information about the Snake River Nitrate Scenario Simulator (SRNSS):

- Description of associated files.

- Initial model settings.

- Creating or selecting datasets.

- Modifying nitrogen loading factors.

- Running the transport model.

- Customizing and viewing the nitrate scenario simulation.

\section{Description of Associated Files}

The simulator is packaged in a compressed zip file for faster download. Table A1 lists and describes the files that are included in the zip file.
Table A1. List of files included in the Snake River Nitrate Scenario Simulator zip file.

\begin{tabular}{ll}
\hline \multicolumn{1}{c}{ File/folder name } & \multicolumn{1}{c}{ Description } \\
\hline readme.txt & Installation and setup instructions \\
SRNSS_setup.exe & Installation program \\
MODFLOW_inputfile_pdfs & $\begin{array}{l}\text { Folder containing PDF files of the } \\
\text { model input data }\end{array}$ \\
\hline
\end{tabular}

The readme.txt file provides instructions for installing the SRNSS.

\section{Initial Model Settings}

When you start the SRNSS software, it loads the base case run shown in figure A1.

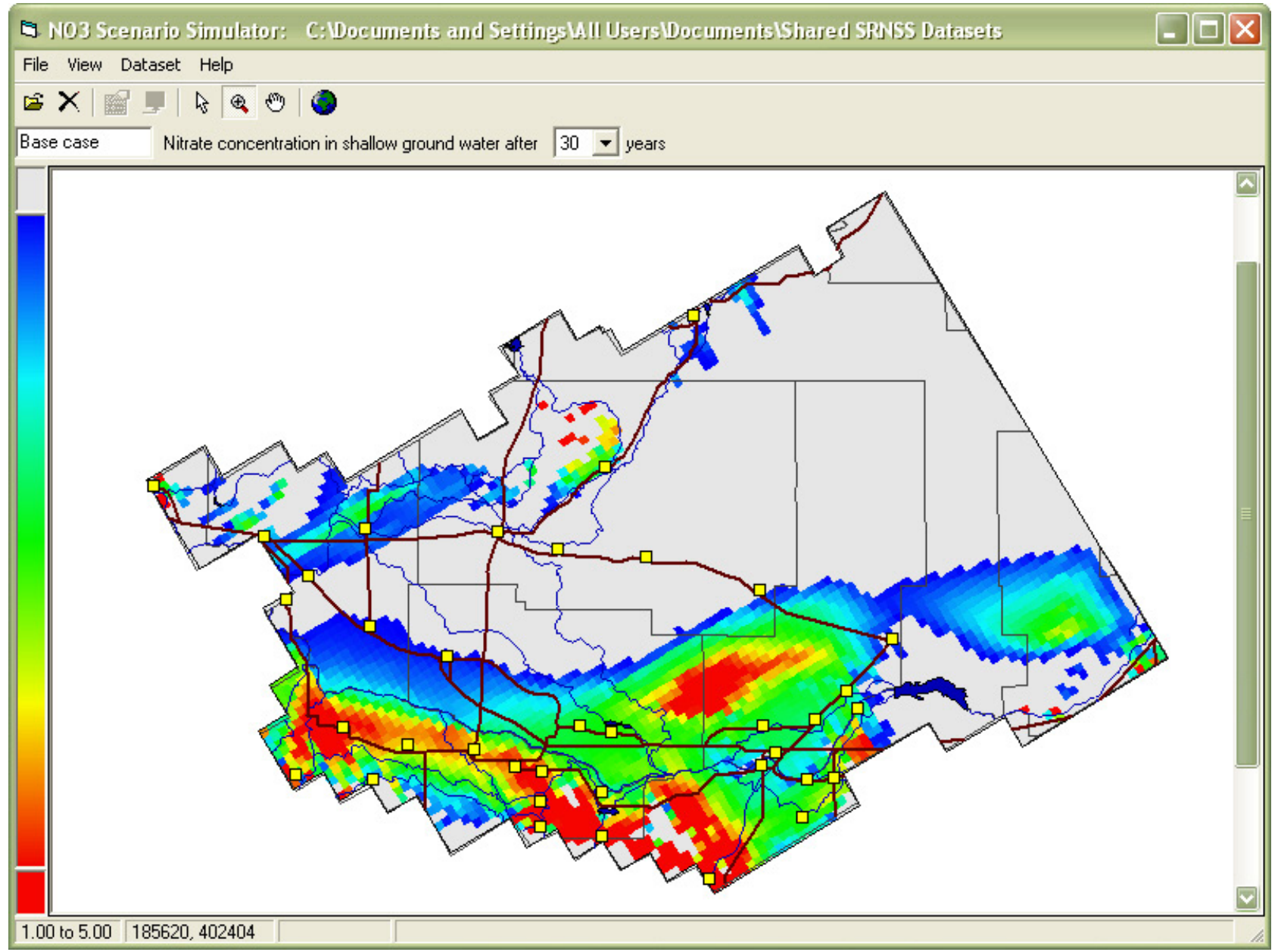

Figure A1. Screen showing base case for the Snake River Nitrate Scenario Simulator, using the spectrum color ramp and minimum/maximum nitrate concentration (nitrite plus nitrate as nitrogen) values set to 1 and 5, respectively. 
The base case run starts with conditions at the end of the 90-year historical period simulation (approximately year 2000). The predictive base case simulation runs for 30 years with constant hydraulic and nitrogen loading conditions equal to those in year 2000. All datasets you create are based on the base case; the datasets differ only in the distribution of nitrogen loading, which you can scale up or down by applying a multiplication factor to any of the 26 pre-defined zones. All datasets are simulated for the same 30-year predictive period as the base case. You can view the nitrate distribution for each run, as well as the change in nitrate concentration in each cell relative to the base case simulation at the same point in time. All nitrate concentrations are nitrite plus nitrate as nitrogen with nitrite concentrations being negligible in the study area.
In figure $\mathrm{A} 1$, the concentration colors have been set to show concentrations between 1 and $5 \mathrm{mg} / \mathrm{L}$ by a smoothly varying color range (blue-cyan-green-yellow-red). By default, cells with concentrations less than $1 \mathrm{mg} / \mathrm{L}$ plot as gray and those with values greater than $5 \mathrm{mg} / \mathrm{L}$ plot as red.

\section{Creating or Selecting Datasets}

The SRNSS lets you create and manage datasets for the flow and transport model. The options to create, select, and delete datasets are available from the simulator's File menu (fig. A2).

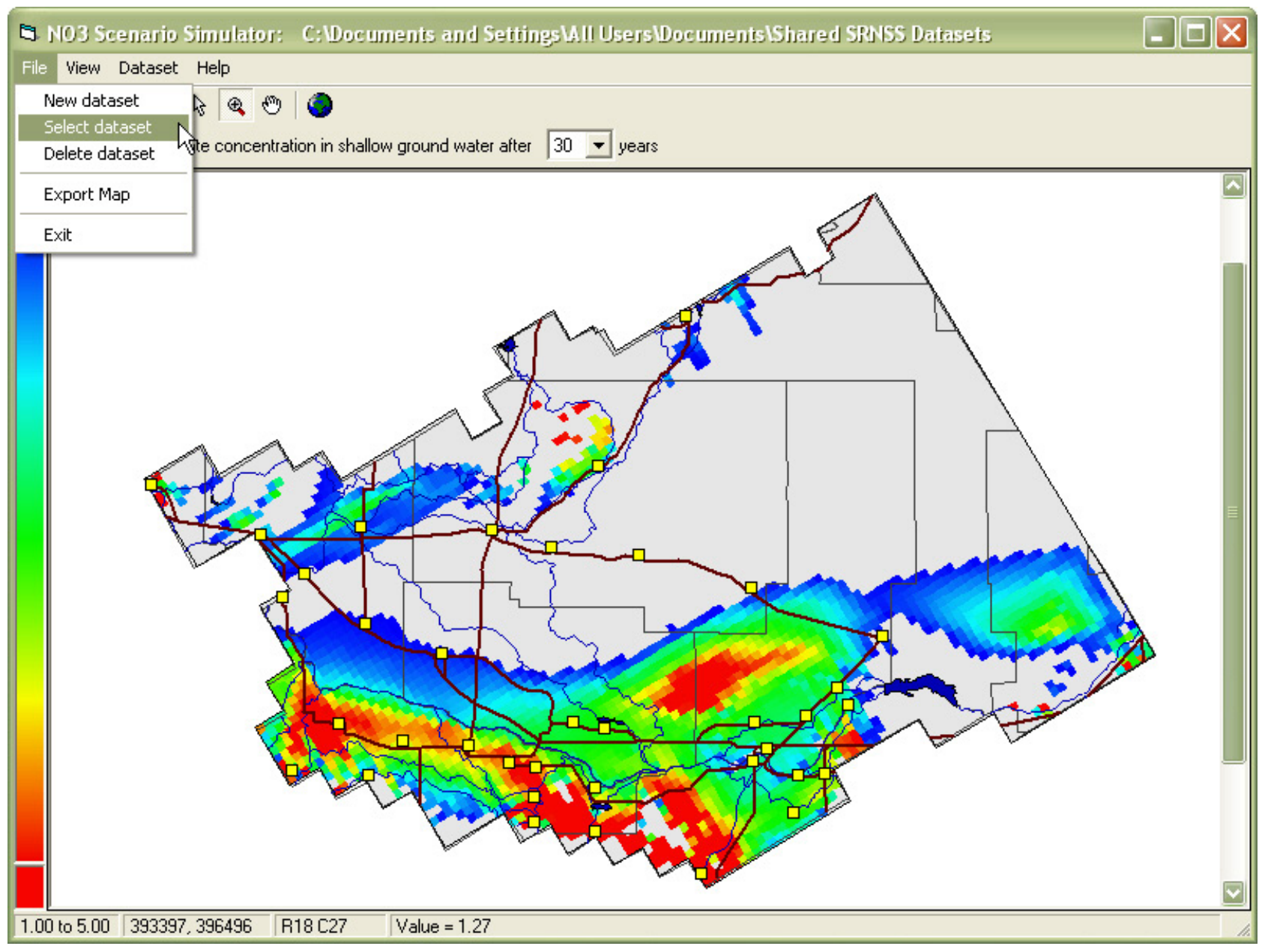

Figure A2. Screen showing dataset management options available in the Snake River Nitrate Scenario Simulator. 


\section{To Create a Dataset}

1. Click File $>$ New Dataset. The New Dataset dialog box displays.

NOTE: By default, the software incrementally names each new dataset as CASE_ \# (where \# represents an incremented number).

2. From the drop-down list, select the existing dataset on which to base the new dataset.

3. Click OK. The new dataset is created. You must now select that dataset to work with it.

\section{To Select a Dataset}

1. Click File $>$ Select Dataset. The Select Dataset dialog box displays, showing the map for the last currently selected dataset (fig. A3).

2. From the drop-down list on the right, select the dataset that you want.

3. Click Select. The dataset is displayed in the simulator (fig. A4).

\section{To Delete a Dataset}

WARNING: If you select the Delete Dataset option, the currently loaded dataset is deleted immediately and cannot be recovered.

Click File $>$ Delete Dataset. The dataset is deleted from the simulator.

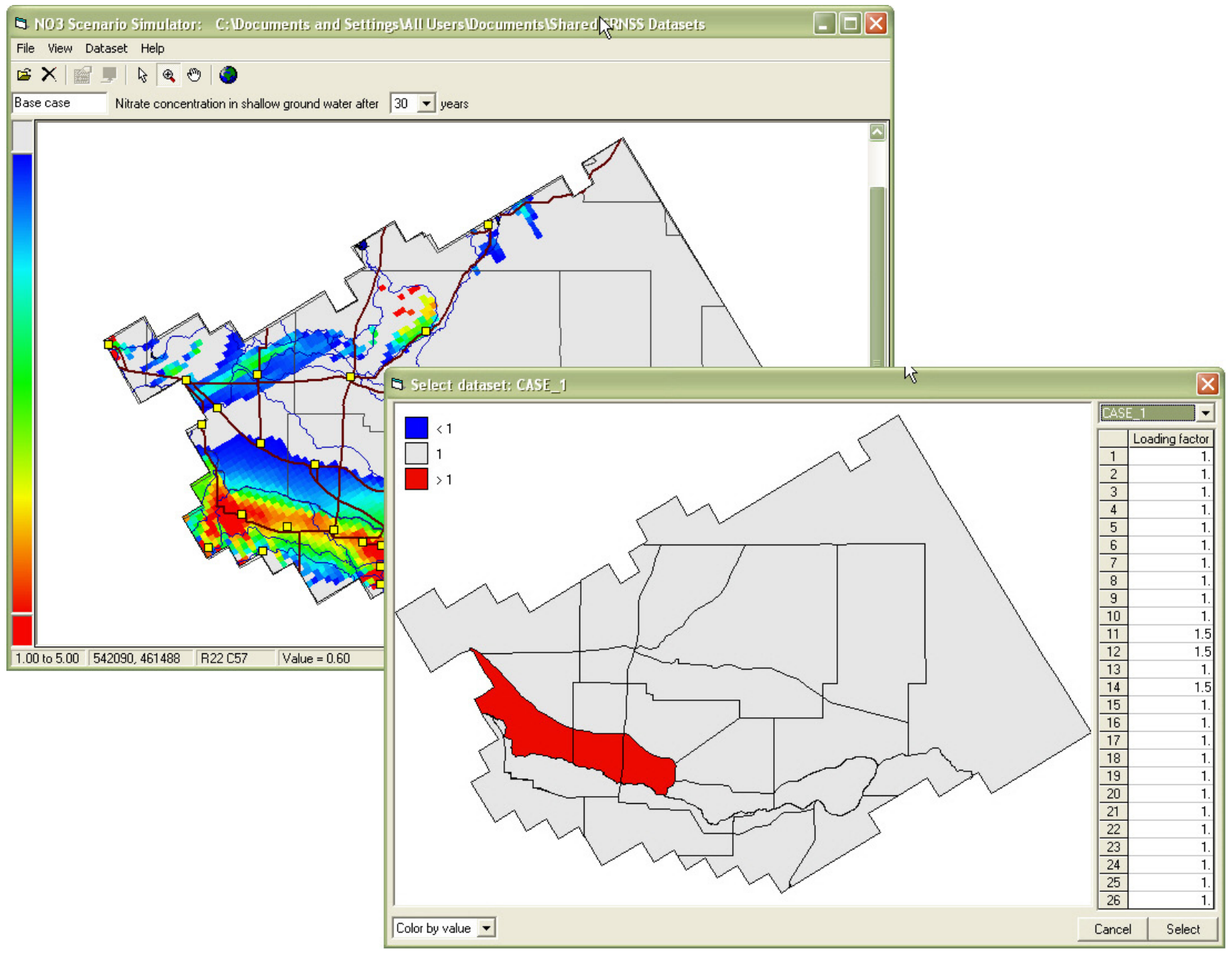

Figure A3. Screen showing Select Dataset dialog box. 


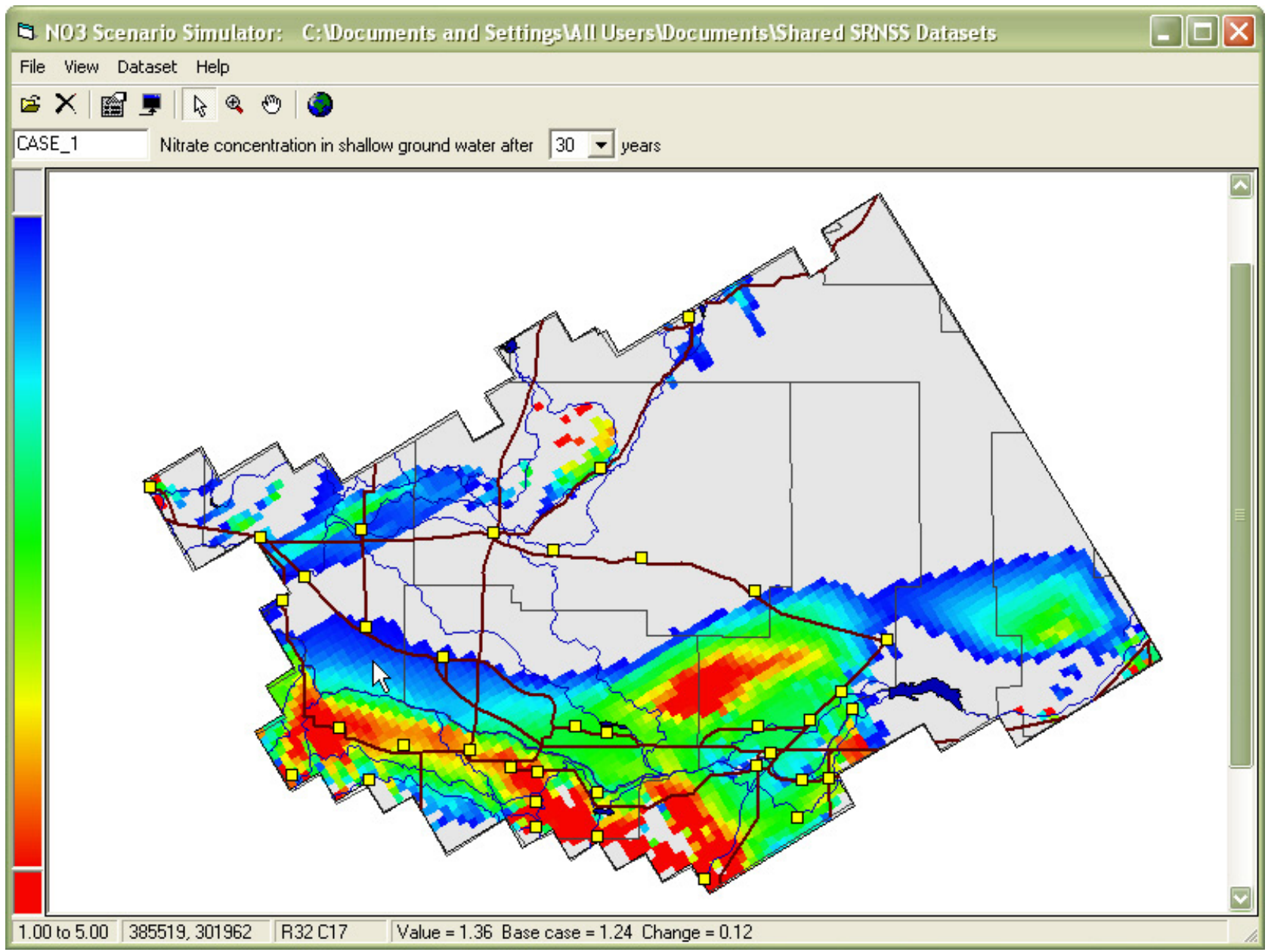

Figure A4. Screen showing selected dataset loaded in the Snake River Nitrate Scenario Simulator.

\section{Modifying Nitrogen Loading Factors}

The SRNSS lets you modify the nitrogen loading factors for any or all of the 26 predefined zones of the mid-Snake region. Each zone's loading factor may range from 0.1 to 5.0. Modifying loading factors lets you create various scenarios to model potential changes in nitrate concentrations throughout the mid-Snake region.

\section{To Modify Nitrogen Load Factors}

1. Click Dataset $>$ Edit loading zones.... The Edit Loading Factors dialog box displays (fig. A5).
2. Do one of the following:

- To assign a value to an individual zone, click the cell for that zone, click Edit Cell Value, and then enter the desired value in the selected cell.

- To assign a uniform loading value to all zones, enter the value in the text box at the top of the screen, and then click Assign Uniform Value.

3. Click Save. The case is updated with the modified load factors, and you are prompted to run the transport model. 


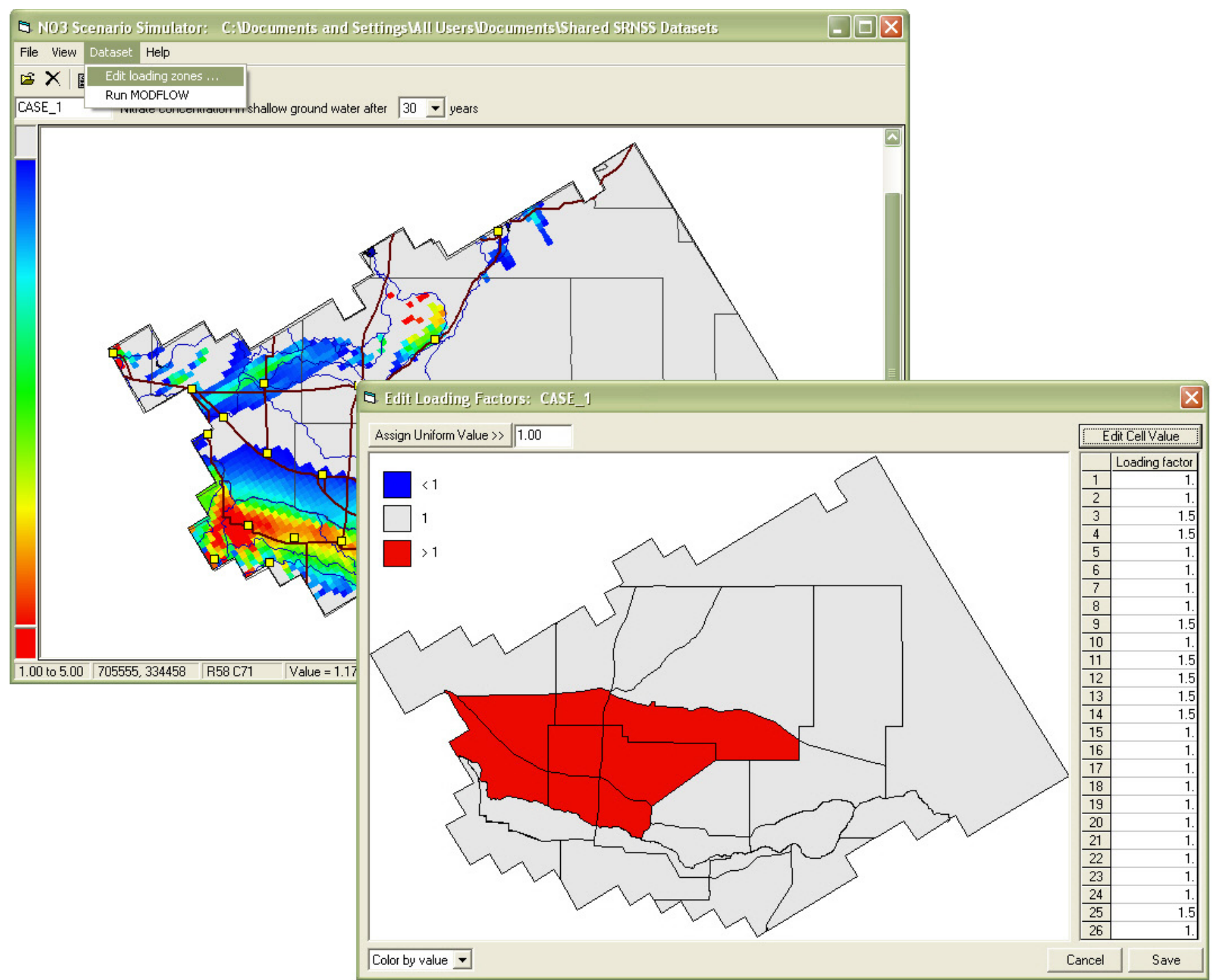

Figure A5. Screen showing Edit Loading Factors dialog box.

\section{Running the Flow and Transport Model}

When you save changes to a dataset's loading factors, the simulator prompts you to run MODFLOW 2000, which in turn runs the flow and transport model (MOC3D). However, you can run the model at any time.

1. Click Dataset $>$ Run MODFLOW (fig. A6). The Run MODFLOW dialog box displays.

2. Click Yes. MODFLOW 2000 runs the transport model MOC3D in a command window (fig. A7).

The simulations take about 15 minutes to run on a 1.7 GHz Pentium 4 computer. After the MODFLOW simulation is complete, the map display is updated with the new concentration values (fig. A8).

\section{Viewing the Nitrate Scenario Simulation}

When the model run completes, the simulator displays the results. You can then simulate potential increases in nitrate concentrations in shallow ground water by selecting time periods ranging from 5 to 30 years. Also, as you move the cursor around the map, note that the status bar at the bottom of the window displays the row-column position of the mouse pointer on the plot. As you hover the mouse pointer over a zone, the status bar displays that zone's nitrate concentration values for both the selected dataset (CASE_1 in this example) and the base case, as well as the change in concentration between the two cases (fig. A4) 


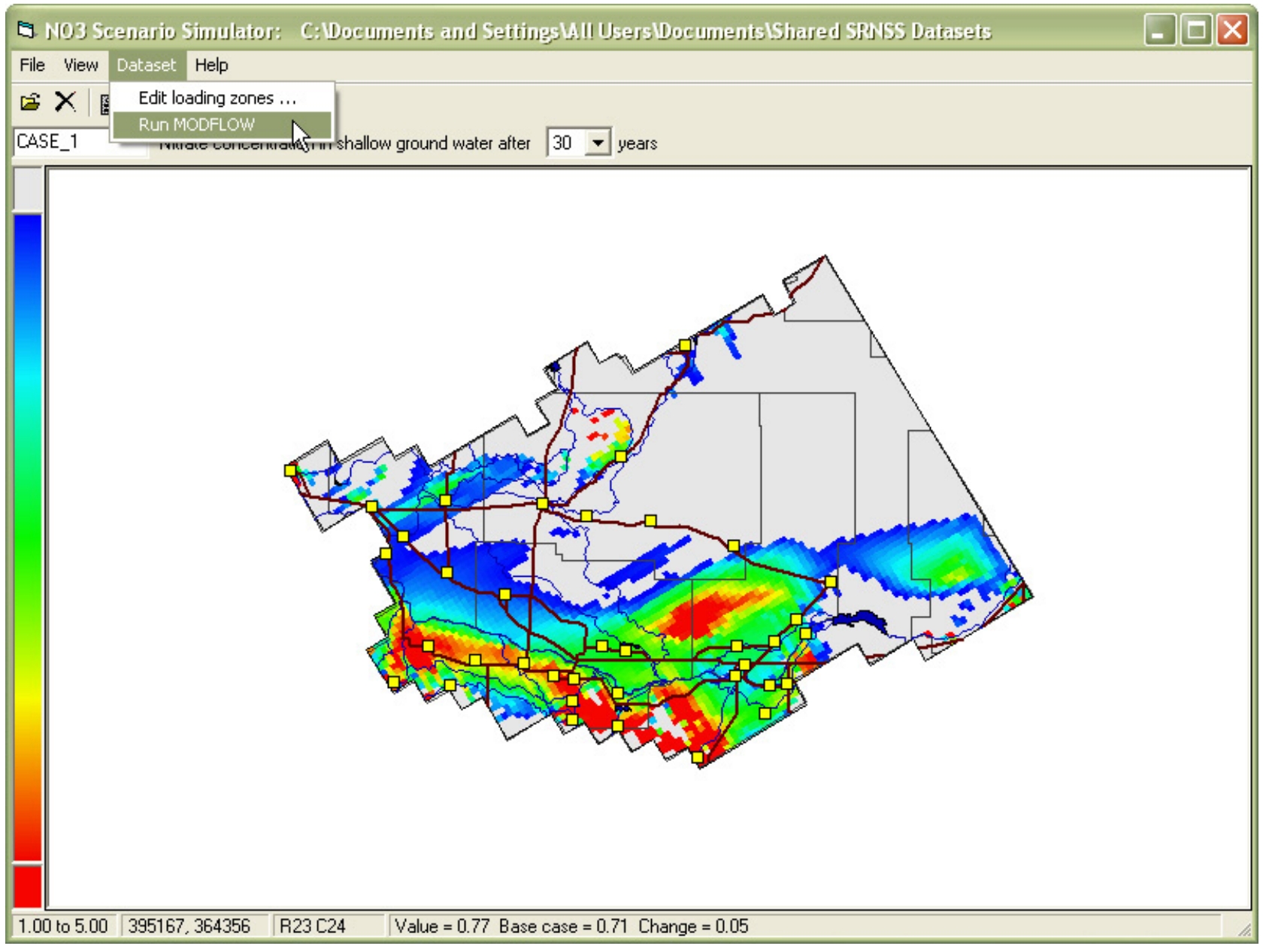

Figure A6. Screen showing the Run MODFLOW option in the Snake River Nitrate Scenario Simulator. 


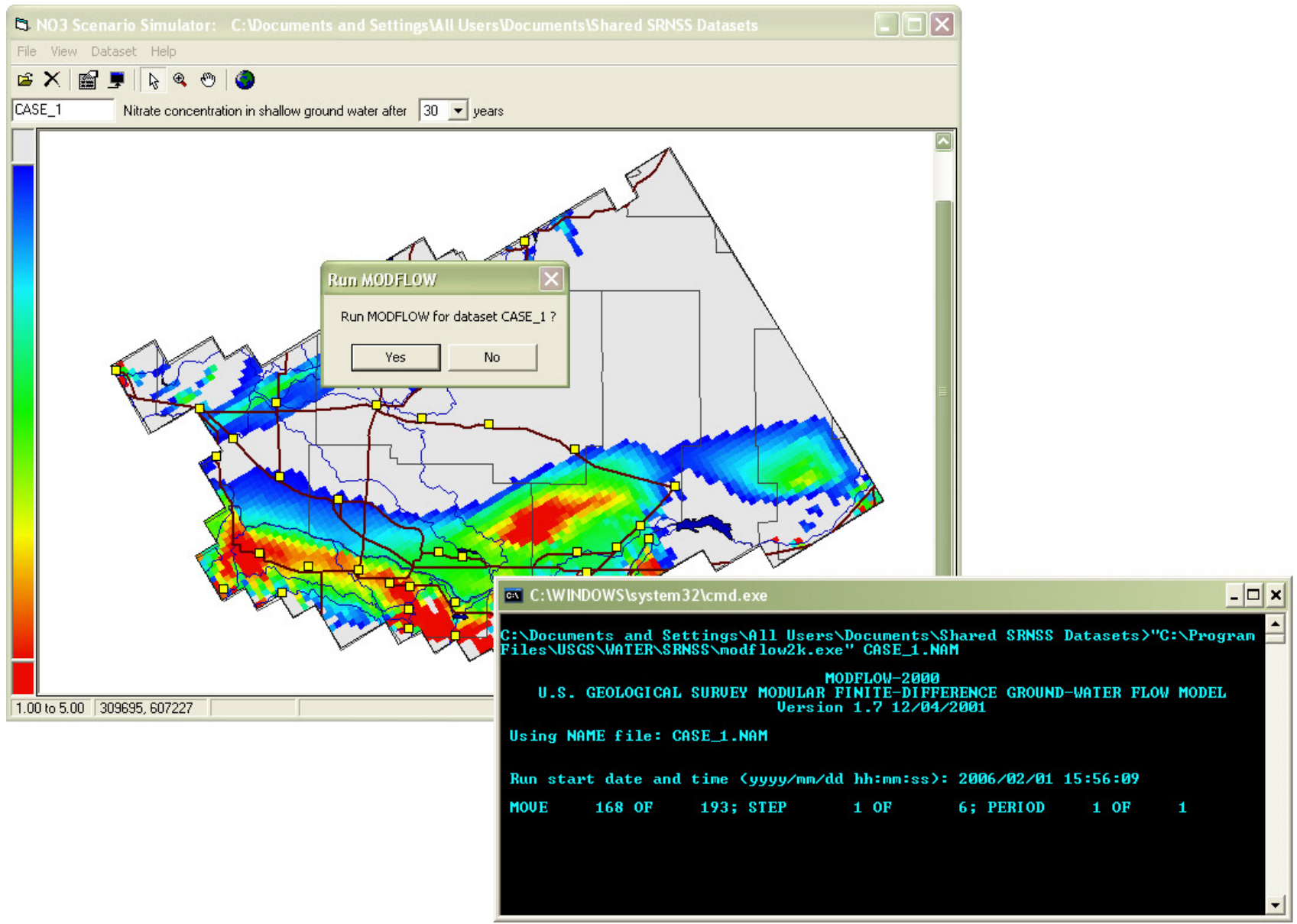

Figure A7. Screen showing MODFLOW 2000 running the MOC3D flow and transport model for the Snake River Nitrate Scenario Simulator. 


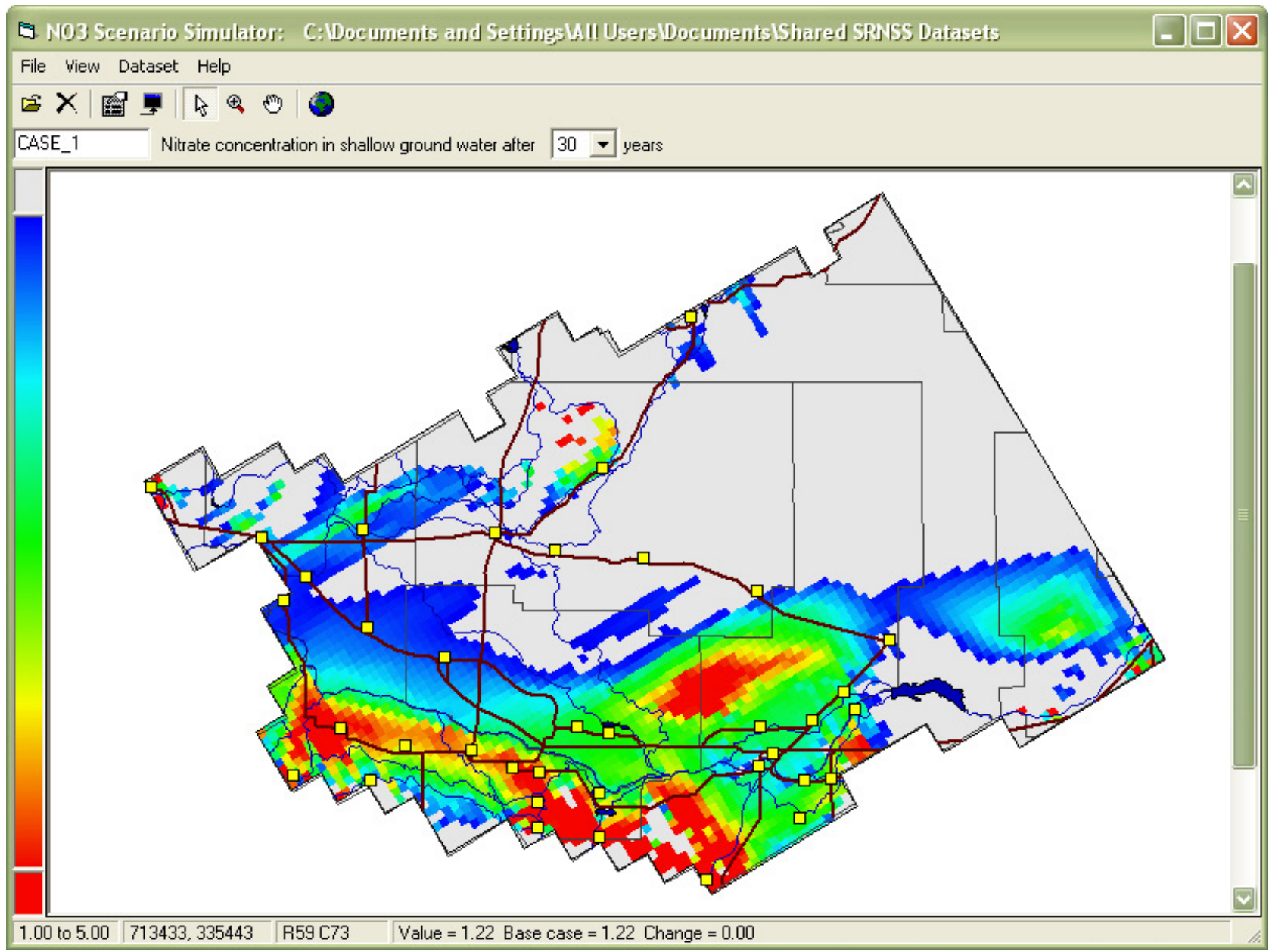

Figure A8. Screen showing plotted results of the MOC3D simulation displayed in the Snake River Nitrate Scenario Simulator.

\section{Customizing the Simulator Display}

The SRNSS provides several options for customizing and viewing the nitrate scenario simulations resulting from model runs. These options include:

- Showing and hiding the model grid.

- Showing and hiding basemap layers for cities, counties, lakes, roads, and streams.

- Selecting rendering options.

- Zooming and panning.
To Show and Hide the Model Grid and Basemap Layers

You can customize the simulation plot by showing or hiding the model grid and the individual basemap layers. These options are available from the View menu (fig. A9). 


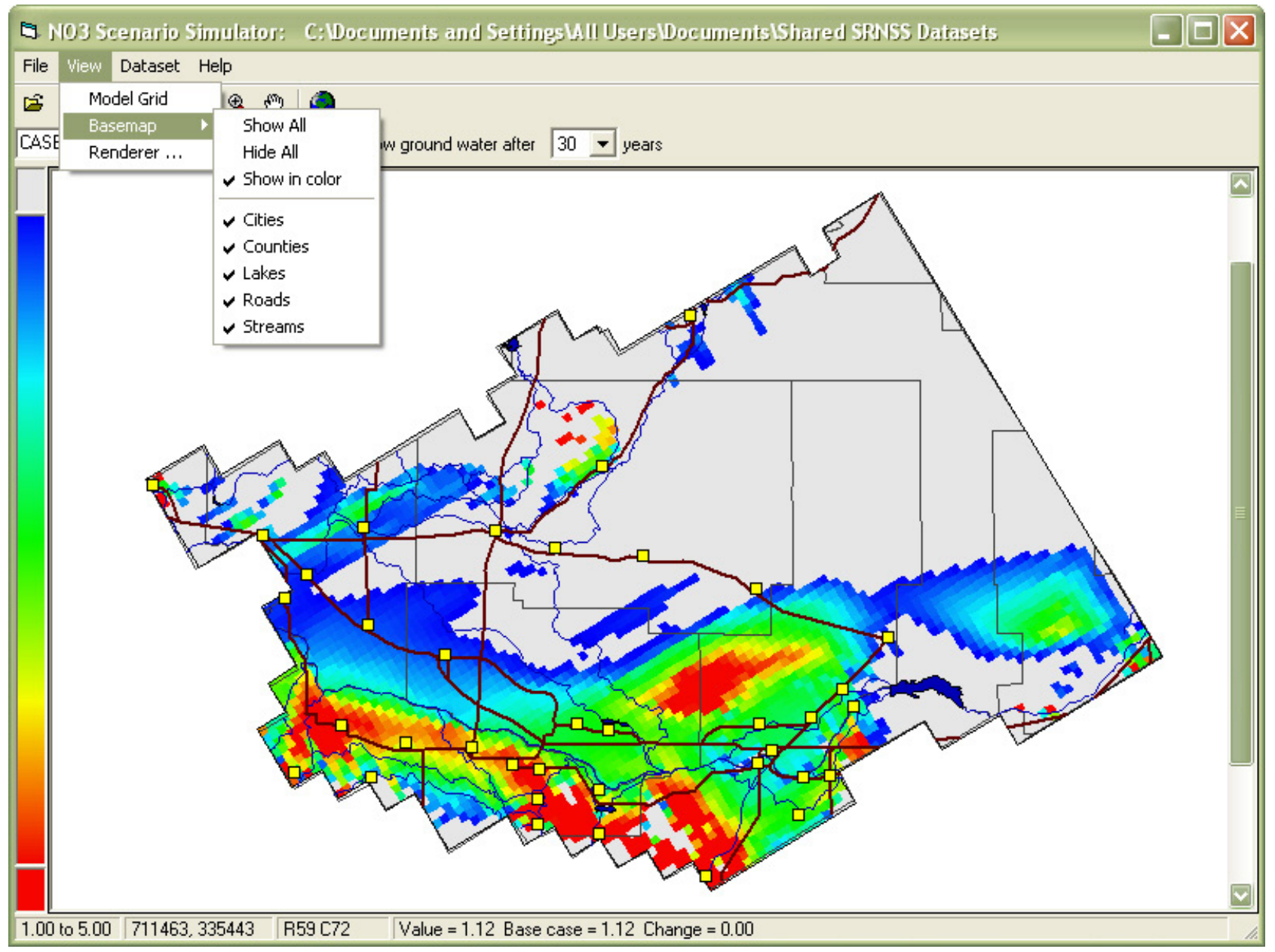

Figure A9. Screen showing customizing the display in the Snake River Nitrate Scenario Simulator.

\section{To Select Rendering Options}

To change the display of nitrate concentration values, select View > Renderer.... The Renderer Properties dialog box lets you select minimum and maximum nitrate concentration values and a color ramp for displaying those concentrations (fig. A10). You also can specify colors in which to display values that fall below or above the defined range. In the example shown in fig. A10, a Spectrum color ramp is selected for data values between 1 and $5 \mathrm{mg} / \mathrm{L}$. Values less than $1 \mathrm{mg} / \mathrm{L}$ will display in gray, and values greater than $5 \mathrm{mg} / \mathrm{L}$ will display in red. By experimenting with the data range and colors, you can focus on different aspects of the simulation data.

\section{To Zoom and Pan}

The plot can be zoomed by selecting the Zoom tool from the toolbar and dragging a rectangle over the area of interest (fig. A11). The plot will then zoom to that extent (fig. A12). You can pan the view of the simulation either by using the scrollbars on the map or by selecting the Pan tool from the toolbar, holding down the left mouse button, and then dragging the mouse. To return to the full view of the simulation, click the globe button on the toolbar.

\section{To Export a Map Image}

The SRNSS software easily allows a user to export an image of the display by selecting File > Export Map (fig. A13). This saves an image of the display to the computer's clipboard or temporary memory to be pasted into another application. This tool does not permanently save a copy of the image to the computer disc. 


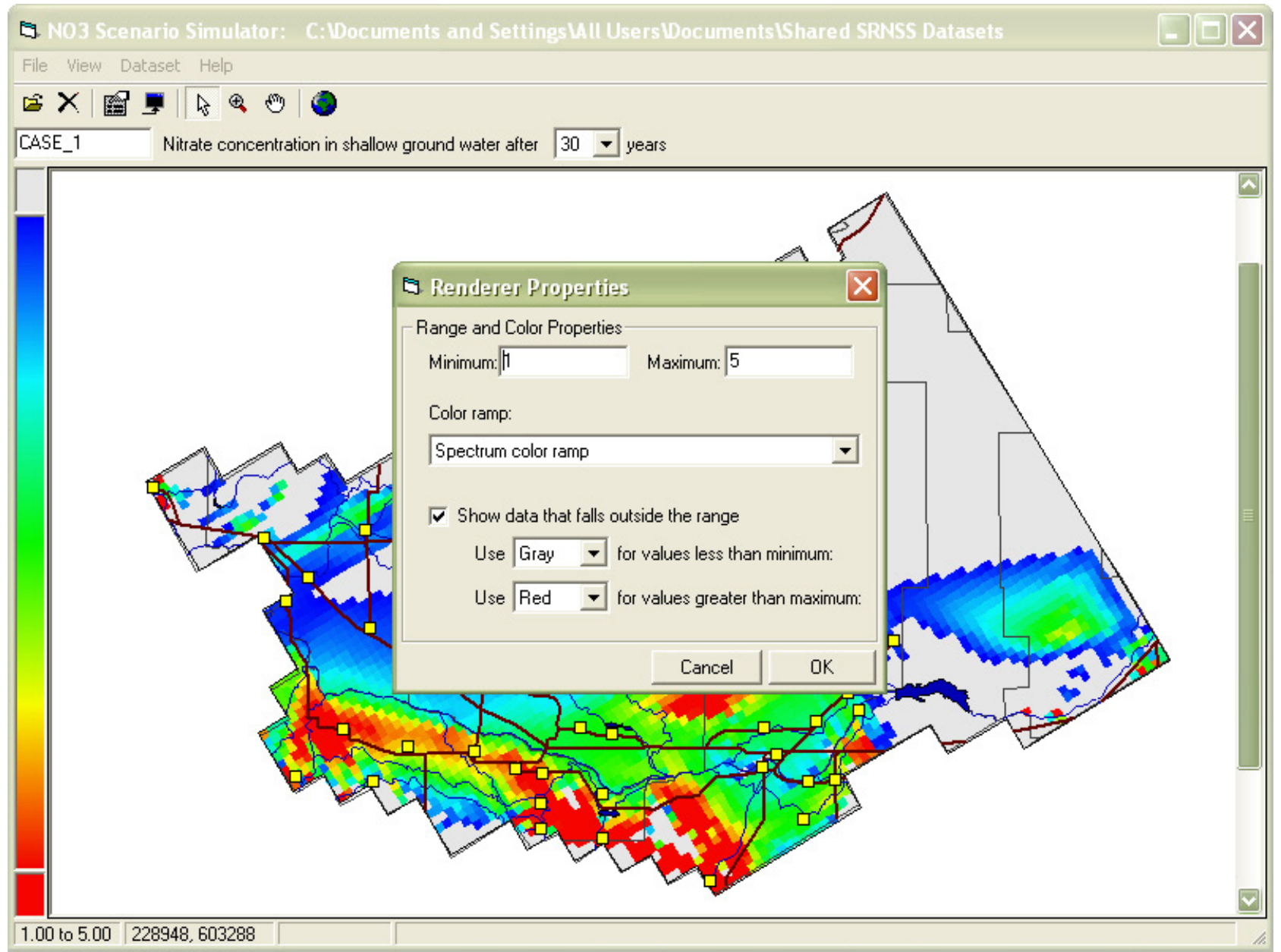

Figure A10. Screen showing options available in the Renderer Properties dialog box. 


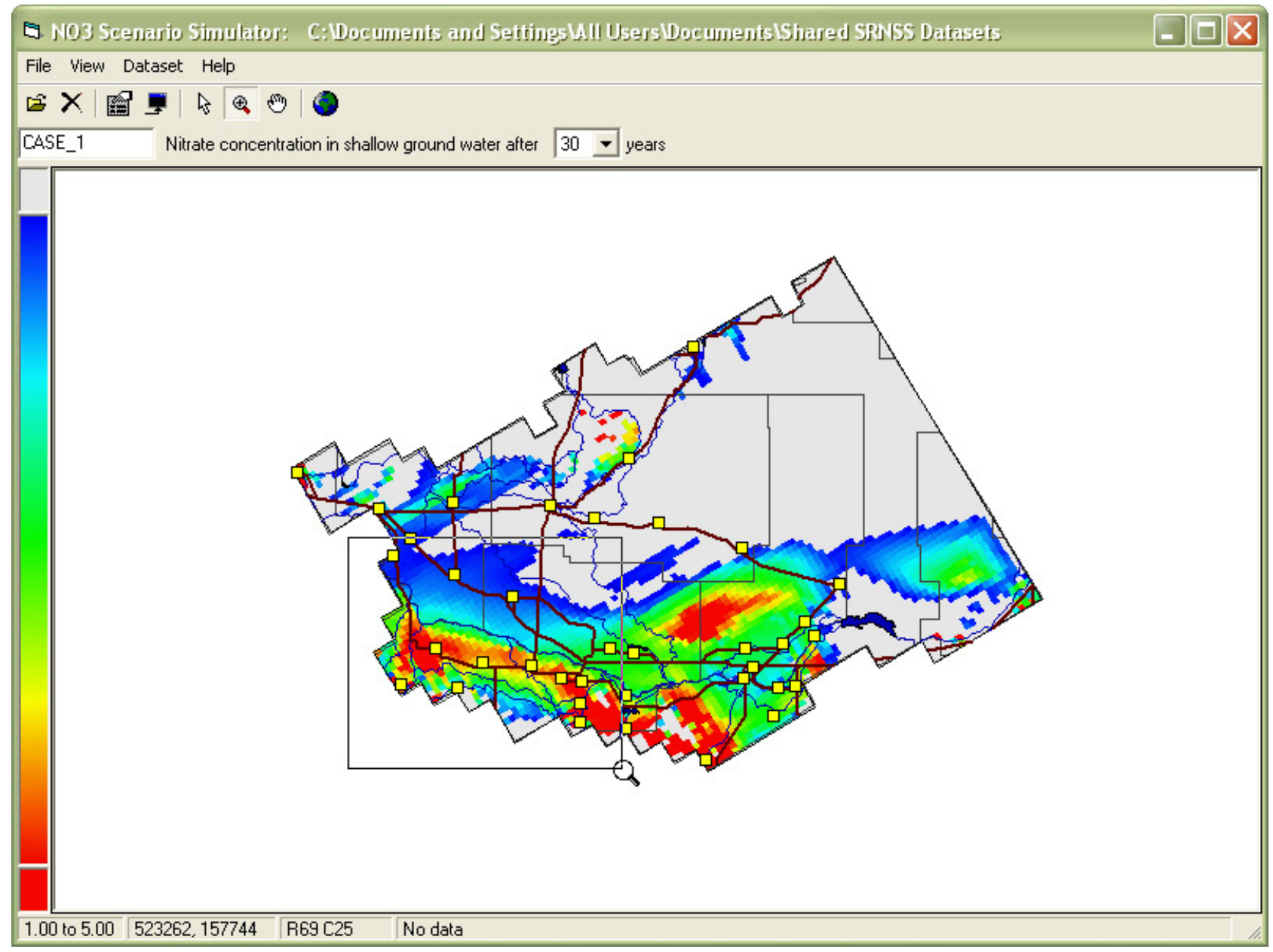

Figure A11. Screen showing use of the Zoom tool in the Snake River Nitrate Scenario Simulator. 


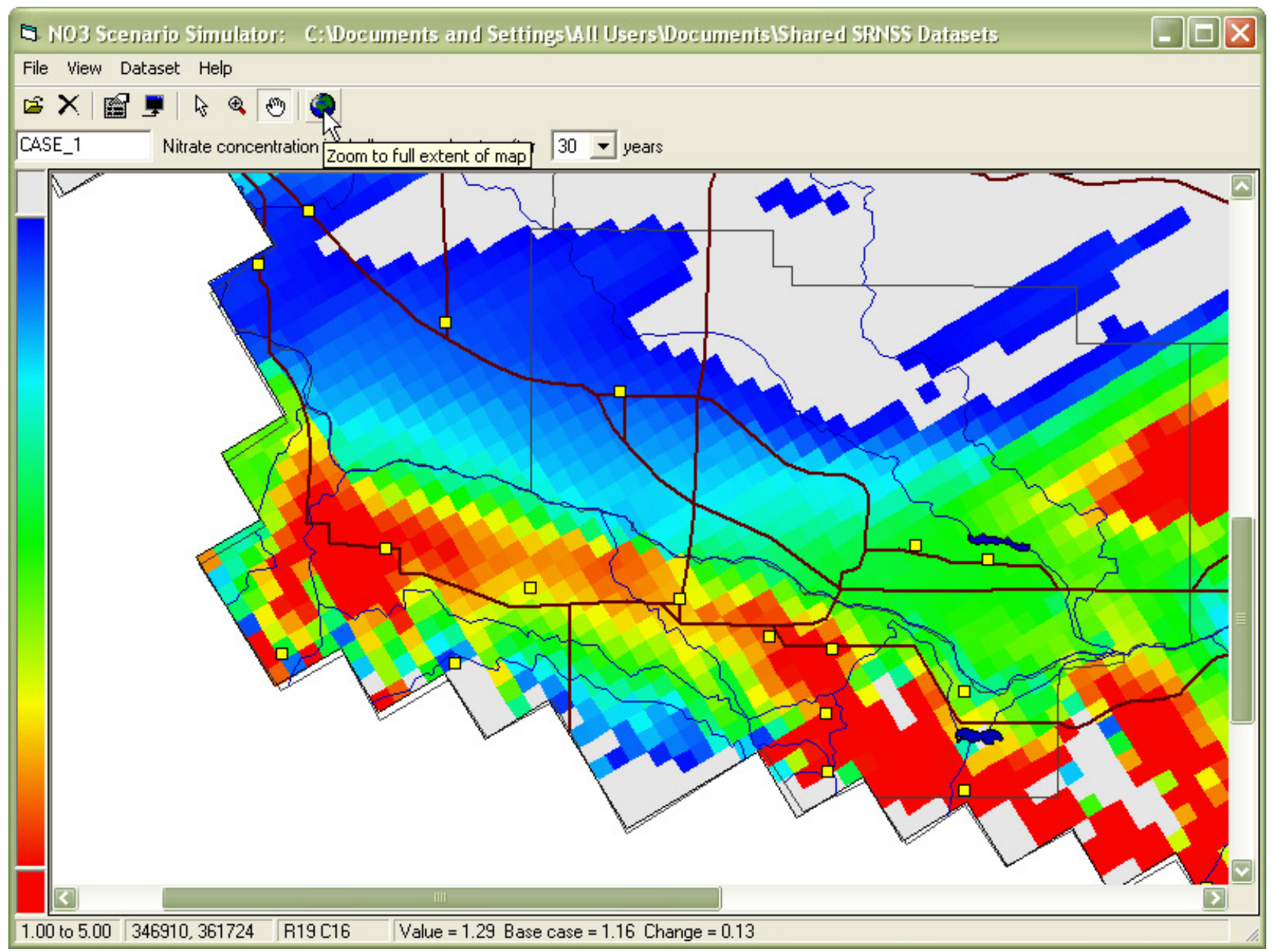

Figure A12. Screen showing a zoomed view in the Snake River Nitrate Scenario Simulator. 


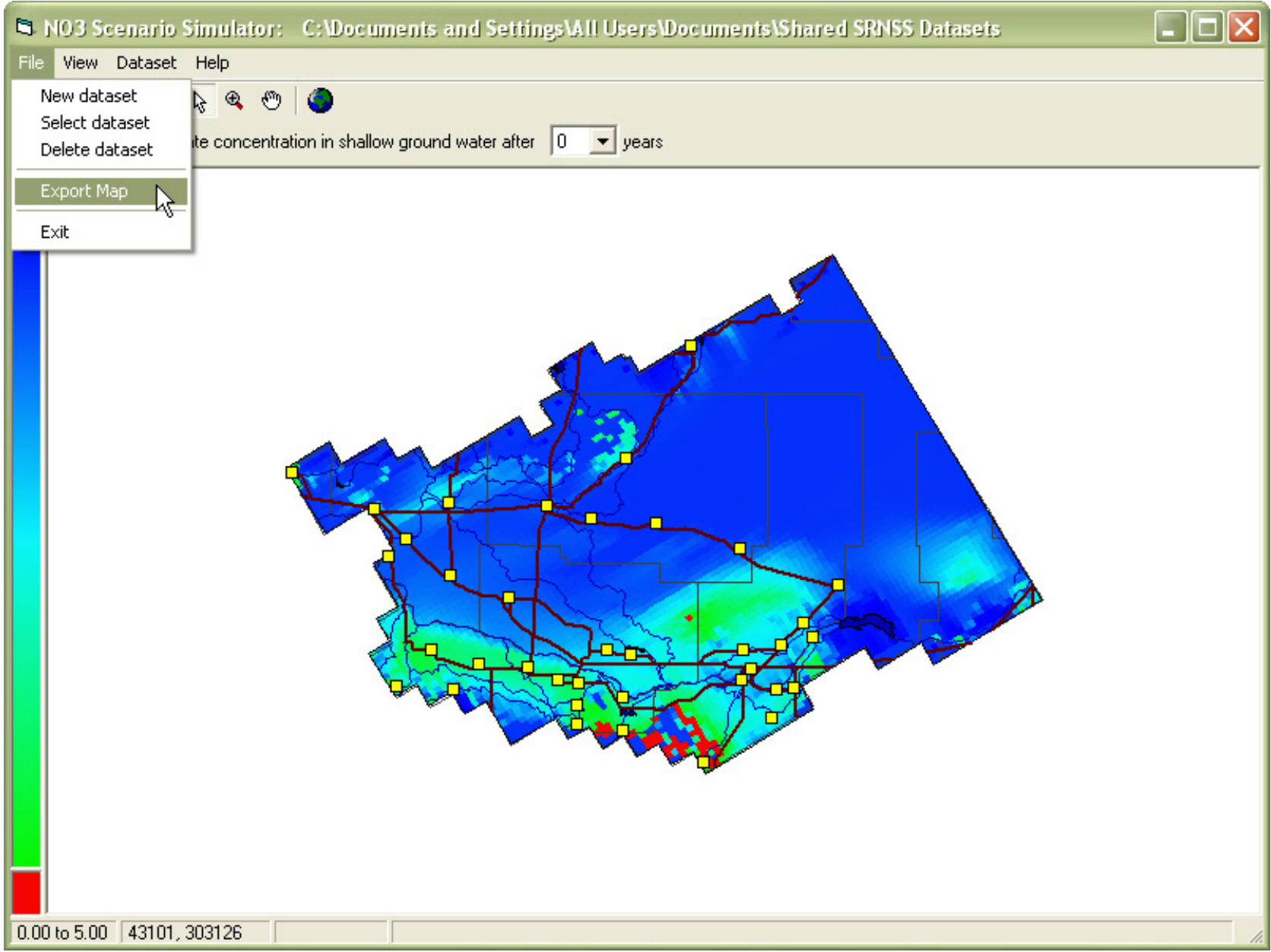

Figure A13. Screen showing use of the export map tool in the Snake River Nitrate Scenario Simulator. 
This page left intentionally blank 
Manuscript approved for publication, June 15, 2006

Prepared by the USGS Publishing Network

Publishing Service Center, Tacoma, Washington

Bill Gibbs

Sharon Wahlstrom

For more information concerning the research in this report, contact the

Director, Idaho Water Science Center

U.S. Geological Survey, 230 Collins Road

Boise, Idaho 83702-4520

http://id.water.usgs.gov 


$$
\text { 总 }
$$

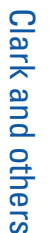

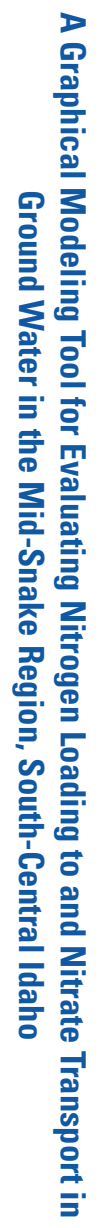

